\title{
AN EGONOMIC ANALYSIS OF TRADING ON PRIVATE INFORMATION BY EXTERNAL ADMINISTRATORS: INTERNATIONAL GOMPARISONS
}

\author{
MICHAEL J WHINCOP+, DAVID J HILLIER*, \\ ALLAN HODGSON++ AND ANDREW MARSHALL**
}

\begin{abstract}
This paper examines the regulation of trades in listed securities by external administrators (EAs), such as trustees in bankruptcy, liquidators, receivers, and administrators on the basis of private information. We consider the economic policy issues associated with such trades. The principal considerations counsel in favour of taking a permissive approach. These are: the difficulties of associating trades with insider information, given the EA's necessarily short expected holding period, the asymmetric application of the insider trading prohibition to sales (rather than decisions not to sell), the market incentives not to misuse private information that apply to EAs, and the unlikelihood that the EA has monopolistic access to the information in question. We consider these considerations by reference to a number of hypothetical scenarios. The paper argues that the law should regulate the subject by coupling a broad exemption for EAs with a "goiod faith" proviso, a continuous disclosure obligation, and a requirement to sell "all or nothing" of a holding of listed securities.
\end{abstract}

+ Michael Whincop, Professor, Griffith Law School, Griffith University, Nathan, Queensland 4111, Australia.

* David J Hillier, Professor, Department of Accounting \& Finance, University of Strathclyde, Glasgow, Scotland G4 0LN, UK.

++ Allan Hodgson, Professor, Amsterdam Graduate Business School, University of Amsterdam, Roetersstraat 11, 1018 WB Amsterdam, The Netherlands.

** Andrew Marshall, Professor, Department of Accounting \& Finance University of Strathclyde, Glasgow, Scotland G4 0LN, UK.

This article forms part of an ongoing research project funded by the Australian Research Council (Large Grant A00104218) and we gratefully acknowledge their support. The article is dedicated to Michael Whincop who passed away during the latter part of this article and we acknowledge the ascendant intellectual capital that Michael provided to the article. We also wish to thank Stephen Bottomley, Richard Nolan and an anonymous referee for their advice and helpful comments as well as suggestions received from a presentation to colleagues at the University of Pennsylvania Law School. The usual disclaimer applies. 


\section{A. Introdugtion}

Viewed across all international jurisdictions, modern insider trading laws have taken three principal forms. ${ }^{1}$ The first and oldest is the American approach, which involves a very general anti-fraud provision, given content by adjudication in insider trading cases. ${ }^{2}$ The second generation of insider trading laws involved more detailed statutory provisions which define the categories of persons who may be insiders and whose use of private information for trading purposes will be prohibited. These categories are usually a category of "primary" insiders, primarily fiduciaries and other executives, and "secondary" insiders who acquire information via primary insiders. This is perhaps the most common form of insider trading law observed in the world today. The English laws, recently redrafted, are a leading example. ${ }^{3}$ The third generation was pioneered in Australian law, ${ }^{4}$ and has been (or is to be) copied in a few other jurisdictions. ${ }^{5}$ It also relies on detailed statutory provisions, but eschews any attempt to define a category of proscribed traders. In place of "person connections", it substitutes "information connections" which aim to catch a wider subset of informed trading. ${ }^{6}$

1 The common law proscribed trading of securities on private information in a limited category of situations. It is arguable that the categories in the United States are somewhat more expansive in the United States: cf. Percival v Wright [1902] 2 Ch 421, Strong v Repide, 213 US 419 (1909). For analysis, see Michael J Whincop, An Economic and Jurisprudential Genealogy of Corporate Law (Aldershot, Ashgate, 2001) 157-161.

2 The principal source of the prohibition on insider trading is the general antifraud provision, rule 10b-5 (17 CFR s 240.10b-5 (2000)), enacted in pursuance of the Securities Exchange Act of 1934, 15 USC s 78 [hereinafter the 1934 Act]. Various federal legislation increases the sanction associated with breach of Rule 10b-5, including the mail and wire fraud statutes, as well as the specific punitive provisions in the Insider Trading Sanctions Act, 15 USC s 78u(d)(2), and the Insider Trading and Securities Fraud Enforcement Act 1988 Pub L. No. 100-704, 102 Stat. 4677 (1988). American law on insider trading does, however, involve other more specific prohibitions of trading on private information. These include the prohibition on short-swing profits (those where sale occurs within six months of purchase) by insiders under s 16(b) of the $1934 \mathrm{Act}$; a duty to disclose or abstain imposed on a person who receives material nonpublic information about a tender offer that originates with either the offeror or the target under Rule 14e-3 under the 1934 Act; and a prohibition on shortselling by insiders under section 16(c) of the 1934 Act.

3 Criminal Justice Act 1993 ss 52-64; Financial Services and Markets Act 2000. Other examples of insider trading laws to predicate insider trading liability on person connections include the European Union approach, embodied in Council Directive 89/592, Co-ordinating Regulations on Insider Dealing; the South African approach, in the Insider Trading Act 1998; the New Zealand approach in the Securities Amendment Act 1988.

4 The Australian insider trading provisions were introduced to the then-extant Corporations Act 2001 by the Corporations Legislation Amendment Act 1991 (Cth Aust.). After the constitutional scheme underlying the Corporations Act 2001 suffered substantial damage, in Re Wakim; Ex parte McNally (1999) 198 GLR 511 and $R v$ Hughes (2000) 74 ALJR 802, these provisions were re-enacted in the same form in the Corporations Act 2001 (Cth), after the states referred constitutional power to the federal government to enact such a law. Change to the insider trading provisions has been foreshadowed by the Companies and Securities Advisory Committee, Insider Trading, Discussion Paper (2001).

5 Malaysia has adopted similar legislation: Securities Industry Act 1983. The Monetary Authority of Singapore is considering adopting analogous legislation: see the Draft Securities and Futures Act 2001.

6 Corporations Act 2001 ss 1002-1002U. 
Each approach has advantages and disadvantages. The American approach has the advantage of considerable flexibility, and can avoid the inherent problem with underinclusion and overinclusion that arises when applying black-letter rules to so complex a subject as insider trading. ${ }^{7}$ Nonetheless, it is not entirely clear that the dominant American approach - the misappropriation theory-has avoided inclusion problems, since, for example, a non-fiduciary who makes a point of stealing information from a corporation is arguably outside the remit of the theory. ${ }^{8}$ Moreover, its underlying rationale has varied confusingly over time, in the face of dogged attempts by the Securities and Exchange Commission to reinstate an underlying theory - equal access to information - rejected by the Supreme Court in the early $1980 \mathrm{~s}^{9}$

The "person connection" approach allows the legislature to commit to a policy, with intuitive appeal from an allocative efficiency perspective, that separates insider trading from the larger category of informed trading. Informed trading is crucial to market efficiency and the accurate and timely reflection of information in stock prices. ${ }^{10}$ The problem with such an approach, however, is that drawing the line ex ante to achieve that balance can be very difficult. This is the problem of underinclusion and overinclusion. Likewise, such proscriptions may encourage proscribed traders to attempt to act strategically to avoid the provision by trading through intermediaries, tipping, and so on (which persons may not be capable of being sanctioned as "secondary insiders"). Moreover, as Ayres and Choi have recently argued, in a challenge to conventional wisdom, it may be that trading by insiders is much less problematic in efficiency terms than trading by outsiders. ${ }^{11}$ To summarise briefly their argument, a corporation is in a reasonable position to permit or prohibit insider trading by its executives and fiduciaries, because it internalises the effect of both the benefits and costs from insider trading. By contrast, outsiders do not bear significant components of both the cost and the benefits of their trades, besides the cost of producing information and the private benefit from the trade. They therefore favour a contractarian approach that allows the firm to decide by whom, and to what extent, "outsider trading" in its securities is permitted.

The "information connection" approach suffers considerably from overinclusion. It fails to register the informed trading/insider trading distinction. In order to avoid those problems, it relies on an appropriate set of defences and exclusions

7 See eg R Phillips and R Zutz, "The Insider Trading Doctrine: A Need for Legislative Repair" (1984) 13 Hofstra Law Review 65; J Cox, "Choices: Paving the Road Toward a 'Definition' of Insider Trading" (1988) 39 Alabama Law Review 381; J Fisch, "Start Making Sense: an Analysis and Proposal for Insider Trading Regulation” (1991) 26 Georgia Law Review 179.

8 Stephen M Bainbridge, "Insider Trading Regulation: The Path Dependent Choice Between Property Rights and Securities Fraud" (1999) 52 Southern Methodist University Law Review 1589, 1621.

9 Chiarella v United States (1980) 445 US 222; Dirks v SEC (1983) 463 US 646.

10 For a review of these arguments, see Jesse Fried, "Reducing the Profitability of Corporate Insider Trading Through Pretrading Disclosure" (1998) Southern California Law Review 71, 303-392.

11 I Ayres and S Choi, "Internalizing Insider Trading" (2001) Yale Law School Public Law and Legal Theory Working Paper No. 04. 
from the legislation, and a prosecution policy designed to filter out inappropriate cases from its extraordinarily wide ambit. At present, the Australian insider trading provisions are under review by the Companies and Markets Advisory Committee. ${ }^{12}$ However, the Committee's initial Discussion Paper presently gives no sign that Australian law will forego its present reliance on information connection tests.

A novel issue to examine in this context is the application of the law on insider trading to persons functioning as the external administrators (EAs) of insolvent companies, such as trustees in bankruptcy, liquidators, receivers, and administrators. ${ }^{13}$ EAs may often come into possession of information that is unknown to the market, for example, information regarding the effect of the insolvency regime, their own intentions, and other matters concerning other market participants. There are two possible uses of such information. They may use that information to trade on their private account. Such a trade would fall into the proscribed category of insider trading in virtually every system - whether as misappropriation, as trading by a primary insider, or as trading on information that is not generally available. On the other hand, the information could also be used in the context of the disposal of marketable securities whose value is affected by the information, which are owned by the insolvent corporation, as part of the administration of its assets. Such a trade would be an instance of outsider (versus "classical" insider) trading, analogous to a business corporation that buys securities based on information generated in the course of its own business. It is this latter situation that we are interested in.

How important is this issue? One way to appreciate it is from the perspective of recent work done in comparative corporate governance scholarship. The basic insight of both the legal and financial economic literatures here is that there are substantial differences in the industrial organisation of corporations of different national economies. One of the hallmark distinctions between the governance of corporations in English speaking jurisdictions from those in other developed economies is the relatively limited corporate ownership of stock by other corporations. This is a contrast to the situation in such economies as Germany and Japan, which have been characterised by a range of inter-corporate holdings through such means as the stock pyramid and the keiretsu. Although less so now than five to ten years ago, commentators urged corporations to adopt some of these features - often described as "relational investing". Clearly, the extent of relational investment determines the scope of concerns associated with informed trading by EAs - the larger these holdings, the more the need to pay attention to the subject.

In one sense, trades of this sort by the EA fall almost entirely through the cracks at every possible point. In the context of the US approach, the EA would not be

12 Companies and Markets Advisory Committee, Insider Trading, Discussion Paper (2001).

13 This is an area of little, if any, research: see, for example RC Pozen and JK Mencher, "Chinese Walls for Creditors' Committees" (1993) 48 Business Lawyer 747. 
in the position of misappropriating information, since the information comes into his hands for the purpose of dealing with an insolvent firm and will (ex hypothesi) be used for those purposes. In the context of the person connection approach, a proscription would rarely arise since the EA ex hypothesi trades on the corporation's account, on the basis of its information. However, an approach which prohibits trading on information that is not generally available would arguably prohibit such a trade - unless there is some available form of defence or exculpation. The Australian legislation is silent on the subject. There is, however, a very brief provision in the Corporations Regulations, inserted not long after the legislation was introduced in 1991. ${ }^{14}$ It exempts certain EAs from liability for insider trading. That provision is curious. On the one hand, it is strikingly incomplete - it includes liquidators and trustees in bankruptcy, but not receivers or voluntary administrators. On the other hand, it is strangely unqualified - it provides a generic exemption for those persons of a sort that is uniquely wide, consequently raising inclusion concerns.

How should these matters be regulated? Is the absence of these trades from the regulatory radar in the United States and most other jurisdictions, and the carte blanche dispensation for liquidators in Australia, a reflection of the fact that there really are no issues worth responding to in these cases? We may view this from several perspectives. Let us first consider three arguments familiar from the insider trading literature. The first is based on the proposition that the law should permit traders to take advantage of information advantages that are capable of being replicated or eroded by other traders. ${ }^{15}$ If one ascribes to this proposition, as so many legal systems do, ${ }^{16}$ at least some of the forms of insider trading by an EA ought to be impermissible. An example is where the knowledge relates to actions that the EA intends to take which would impose costs on some other party, such as a decision that would disadvantage unsecured creditors. That information is often difficult or impossible to replicate by research.

Secondly, consider the view that permissions or exemptions for some forms of trading on private information preserve incentives to produce new information, which will in time be impounded into the price of securities. ${ }^{17}$ If that is true, it is difficult to think that there are any forms of information that the EA would not, in

14 Corporations Regulations 1990 reg. 7.11.01(1).

15 See, V Brudney, "Insiders, Outsiders, and Informational Advantages Under the Federal Securities Laws" (1979) 93 Harvard Law Review 322, 354.

16 See Ayres and Choi, above $\mathrm{n}$ (making the claim that prohibiting the use of an unerodable informational advantage explains the US system) and the Corporations Act 2001 (Aust) s 1002B(2), (3) (making exceptions for information deduced or inferred from what is in the public domain). In the UK the Financial services and Markets Act 2000 was set to protect the integrity of the UK's financial markets by creating a new regime to tackle market abuse. This regime compliments existing laws dealing with misconduct in financial markets. The central part of the regime is contained in the Code of Market Conduct (FSA Handbook 2004).

17 See generally AT Kronman, "Mistake, Disclosure, Information, and the Law of Contracts" (1978) 7 Journal of Legal Studies 1. 
any event, produce in the absence of a permission or exemption. This information is generated in the course of the administration of the insolvent firm, so the marginal gain to the total stock of information is minimal or zero.

Thirdly, many of the defences of insider trading, beginning with Henry Manne's historic analysis, ${ }^{18}$ have used an argument to the effect that insider trading is ex ante in the best interests of shareholders as a whole. The characteristic argument in this context is that insider trading helps to improve managerial incentives in light of managerial risk aversion and the problems associated with writing an optimal compensation contract. It is obvious, however, that this argument can cut but little ice in the context of trading by the EA. Where the liquidator of a company, XYZ, trades in the securities of JKL on private information known to her, one is immediately struck by the externality concerns that Ayres and Choi evaluate - the trade will make uninformed shareholders in JKL worse off, to the extent the liquidator earns an abnormal return, with few or no compensating benefits of other forms for them. Moreover, the gains (the informational rents) do not even accrue to other shareholders, but rather to creditors of the insolvent firm. We may adopt the heuristic method of Ayres and Choi to ask whether under zero transaction cost assumptions, the shareholders of XYZ would successfully engage the shareholders of JKL in a Coasean trade under which the former shareholders paid for the right for a liquidator appointed to the firm to trade on private information. Although the shareholders of XYZ might willingly pay something for this right - based on the fact that it may lower the cost of capital ${ }^{19}$ - it is hard to say that they will always (or, indeed, ever) value this right higher than the shareholders of JKL. So, we might provisionally conclude that the economic case for allowing informed trading by an EA seems to be quite weak.

The implication of this analysis is not that economics requires us to proscribe informed trading by an EA, but to recognise that the existing arguments in relation to insider trading do not exhaust all of the factors relevant to trading by outsiders, especially in the context of EAs. In this paper, we proceed by demonstrating a series of cases which reveals the effects arising in these situations. When generalised, they suggest four basic points.

First, permitting informed trading by insiders may reflect the difficulty of associating a trade with the private information. Given that insolvency is frequently associated with the realisation of assets, it will frequently be the case that the trading strategies of the EA will look identical, whether or not the EA was in possession of that information. Some legal systems provide defences where insider information is deemed not to change trading behaviour or enable parties to adopt trading strategies that are unaffected by later insider information, however, in the UK according to the FSMA s 118(10) the types of behaviour which come within

18 Henry G Manne, Insider Trading and the Stock Market (1966).

19 The right would lower the cost of capital because it would allow the insolvent estate to earn abnormal returns, rather than market returns. 
the scope of the market abuse regime also includes inaction. These are crucial in the context of insolvency where the information relates to the actions of an external administrator, since expeditious realisation may be at least desirable and in some cases mandatory. To prohibit insider trading in these circumstances would be tantamount to imposing a mandatory rule that the EA would be required to dispose of securities in a manner least favourable for the insolvent estate, inconsistently with the general law applying to the EA or a contractual duty. A rule permitting informed trades is most consistent with the duties and accountabilities of the EA to creditors.

Secondly, various commentators have pointed out the fact that insider trading regimes never include in their ambit the use of private information to reach a decision not to trade or to postpone trading. ${ }^{20}$ When we recognise this point, the case for exempting trades by EAs from a prohibition is especially strong. This is because the relative importance of the postponed trade is even greater to the EA since there is only one other plausible trade for an EA - a trade brought forward. When combined with the difficulty of associating trades with information, the inherent importance of the permitted but postponed trade argues for an exemption for trades brought forward if the system is not to be capricious.

Thirdly, the EA's reputational capital will frequently deter an EA from trading in a way that is regarded as inappropriate by market participants. In general, insider trading can be hard to detect, but the EA's trades will usually be easy to identify in retrospect. In these circumstances, the market for EAs will sanction the EA by devaluing the EA's reputational capital where the EA has overreached, acted negligently, or, in some other respect, acted inconsistently with the interests of creditors. Rational EAs will therefore choose not to engage in these behaviours. $^{21}$ These reputational incentives are supplemented, consistently, by the general law or contractual duties the EA owes in relation to the discharge of his duty.

This article is organised into four substantive parts. Section B discusses the anatomy of informed trading by insiders. It is important to understand not only the circumstances where insider trading is an issue, but also something of the spectrum of cases which may possibly arise. Section $\mathrm{C}$ then provides an overview of some of the legal issues that may arise in these cases. The treatment is intended to be non-specific to any single jurisdiction, but instead has regard to the key incidents of the three genera of insider trading laws we have referred to above. Section $\mathrm{D}$ examines some of the principal policy issues which arise in these cases. We consider first the implications arising from the application of the factors reviewed

${ }^{20}$ For example, Reinier Kraakman, "The Legal Theory of Insider Trading Regulation in the United States", in Klaus J Hopt \& Eddy Wymeersch (eds), European Insider Dealing (London, Butterworths, 1991) 48; Henry Manne, "Insider Trading and Property Rights in New Information" (1985) 4 The Cato Fournal. 933, 938. Cf. Jesse M Fried, "Reducing the Profitability of Corporate Insider Trading through Pretrading Disclosure" (1998) 71 Southern Caifornia Law Review 337-340.

${ }^{21}$ It is, however, true that the value of an EA's reputational capital is not perfectly consistent with social welfare, since the value of the reputational capital will mostly be set by lenders and bondholders, rather than shareholders. 
in the general insider trading literature and then move on to explore a series of factors more specific to EA cases. In this section, we address the implications of our analysis for a variety of hypothetical examples introduced illustratively in Section B. Finally, in Section E we consider whether more specific regulation is needed in this area, examining the implications of more tailored provisions relating to trading and of more specific disclosure obligations. The article is concluded in Section F.

\section{B. The Anatomy of Informed Trading by External Administrators}

\section{Introduction}

This section develops a more specific understanding of what is involved and the issues that arise in situations that involve informed trading by external administrators. Apart from the introductory comments in this section, we introduce a taxonomy of cases designed to allow the reader to understand the variations in cases that might arise in these areas, and introduce a series of illustrative hypotheticals. These hypotheticals are reused in Section D, after we analyse informed trading by insiders.

To begin, we must first appreciate that informed trading by an EA only becomes an issue where the insolvent firm owns securities, and in particular traded securities. If the firm owns securities that are not traded, the EA will usually need to sell these by private contract of some form with a buyer that will occur dehors any exchange. In that context, it may be required to give warranties or undertakings regarding certain facts or situations relevant to the value of the securities. The purchaser may demand and be granted the opportunity to investigate and undertake due diligence into the circumstances of the company in which the securities are sold. ${ }^{22}$ The common law itself may oblige certain special facts to be disclosed by the vendor. ${ }^{23}$

Where however the securities are exchange-traded, then there may be scope for asymmetrically informed trading by the EA. Why would a firm own exchangetraded securities? As has been argued in detail in the finance literature, there is no particularly good reason for the firm to own these securities, since its own shareholders can replicate that security holding in their own portfolio should it be valuable. ${ }^{24}$ That is not to say that firms will not hold such securities. Risk-averse managers, rationally undiversified, may value the potential diversification effects. In addition, the securities may be held for reasons other than their risk-return

22 Fordan v Duff and Phelps, Inc., 815 F2d 429, 431 (7th Cir. 1987).

23 See, eg, Strong v Repide, 213 US 419 (1909); Glavanics v Brunninghausen (1996) 19 ACSR 204; on appeal (1999) 32 ACSR 294.

${ }^{24}$ RA Brealey and SC Myers, Principles of Corporate Finance, (New York, McGraw Hill, 7th ed, 2002). 
properties. One important reason is that the investment supports some form of business relation with the other corporation, which relation might be motivated either by efficiency reasons or monopoly. ${ }^{25}$ Investments in firms may also be a part of a series of commitments that each firm gives to the other. The existence of that sort of relation also makes possible the potential for the insiders in that firm (including the EA) to possess information relevant to the value of those securities, and, therefore, the scope for informed trading.

The potential existence of private information may derive from a range of sources. Several possibilities suggest themselves. The first is that the administration of the insolvency may itself change the valuation of certain firms, some of which the insolvent firm may hold securities in. Secondly, the EA must undertake a process of valuing the firm and its investments. In doing so, new information will be generated that may be relevant to the value of other securities. Thirdly, the conduct of the external administration such as the proof of debts or the investigation of possible causes of action may reveal new information about other traded firms. In the next section, we see how these different sources of information can be harnessed to permit the development of a taxonomy of cases.

\section{A Taxonomy of Cases}

The taxonomy developed in this section has two dimensions. The first dimension involves the process by which the EA came into the possession of the information. The second dimension refers to the relation between the source of information and the ownership of the securities involved in the informed trade, specifically whether or not the information was generated in connection with the insolvency in which the trade takes place.

To examine the first dimension, we may distinguish three different processes by which the EA comes into possession of the information. First, the information can be endogenous to the insolvency - in other words, the information itself is about the economic effects of the insolvency. Secondly, the information may be generated by the EA in the course of the insolvency and the discharge of the administrator's duties. Thirdly, the information may simply have a coincidental connection with the insolvency, as where the EA is informed of some matter by another party in the course of performing the duties of the administration. The distinction between the two latter categories is not precise.

To examine the second dimension, we may distinguish between whether or not the information was generated in connection with the insolvent estate whose securities are the subject of the informed trade. On the one hand, the information may arise in the course of administering insolvent company A, and be used to trade securities owned by company A. Alternatively, the information may be used

25 For example to guarantee material supply, labour, management quality, marketing output, or to increase vertical or horizontal efficiencies and hence market power. 
to trade securities owned by company B, for which the EA also acts. Obviously, these issues resonate with concerns about conflicts of interest. We may describe these as intra-insolvency and inter-insolvency trades.

If we cross these two dimensions, we can identify six different possible scenarios involving some form of informed trading by the EA. These are set out in Table 1.

Table I: Taxonomy of Informed Trades occurring in Insolvent Firms

\begin{tabular}{|c|c|c|}
\hline & Intra-insolvency Trades & Inter-insolvency Trades \\
\hline Endogenous information & $\begin{array}{l}\text { Intra-insolvency trades on } \\
\text { endogenous information }\end{array}$ & $\begin{array}{l}\text { Inter-insolvency trades on } \\
\text { endogenous information }\end{array}$ \\
\hline Generated information & $\begin{array}{l}\text { Intra-insolvency trades on } \\
\text { generated information }\end{array}$ & $\begin{array}{l}\text { Inter-insolvency trades on } \\
\text { generated information }\end{array}$ \\
\hline Coincidental information & $\begin{array}{l}\text { Intra-insolvency trades on } \\
\text { coincidental information }\end{array}$ & $\begin{array}{l}\text { Inter-insolvency trades on } \\
\text { coincidental information }\end{array}$ \\
\hline
\end{tabular}

It would also be possible to identify a third dimension - whether or not the EA traded on that information or whether he tipped or procured another trader using the information. This situation, however, involves similar issues to those arising in cases of inter-insolvency trades. Section $\mathrm{G}$ examines each of these trade types in more detail and uses illustrations to clarify the issues they raise.

\section{Illustrating the Taxonomy}

\section{(a) Intra-insolvency trades on endogenous information}

In this situation, the private information in question arises from the conduct of the insolvency, and its economic effects on other firms. Prominent examples might include decisions to be taken by the EA to realise assets, to refuse to accept a proof of debt, or to commence litigation in order to pursue a right to damages. Such information is necessarily generated during the course of the insolvency, and, to the extent of any divergence from market expectations, the EA will always have first access to it. Scenarios 1 and 2 illustrate what is involved in the case of intrainsolvency trades on endogenous information.

\section{Scenario 1: L, a liquidator of company $C$ is considering initiating a suit on behalf of $C$ against company $D$ alleging misleading and deceptive conduct. Company $C$ holds stock in $D$.}

In Scenario 1, the information relates to the fact of the suit and the costs and expected damages award it will occasion. The market may have expectations about the likelihood of a suit against D; however, unless the expectation is that 
the suit has a probability of either zero or unity, a decision to continue a suit (or to discontinue a suit) will always constitute new information.

\begin{abstract}
Scenario 2: $R$, a receiver of company $C$, appointed by bank $B$ under a floating charge, has been made a private offer by a purchaser $P$, who is willing to buy the business undertaking of $C$. The next-best alternative to selling the business to $P$ is to run the business for a further twelve months, to complete the development of a product. C's only other asset, besides the business, is a holding of (listed) securities in company $D$ (currently worth $\$ 2$ million). C undertook a number of business projects with $D$, and owes $D$ a large unsecured debt. $B$ is currently owed $\$ 10$ million, and that debt bears interest at the rate of $10 \%$ pa. $C$ has unsecured debts of $\$ 20$ million, half of which is the debt to D. Apart from the $\$ 10$ million debt owed by $C, D$ has other assets valued at $\$ 15$ million. P has offered $\$ 8$ million for the business. If $R$ chooses to run the business for a further 12 months, there are two equally likely outcomes - the business will be worth $\$ 8$ million or $\$ 31$ million. The information about that valuation is generally available. $R$ is instructed by $B$ to sell the undertaking and not to develop the company business.
\end{abstract}

In Scenario 2, the private information is the fact that the disposition of the assets of the business that is optimal for B has altered from the going concern development to the sale; and the impact this will have on payoffs to D and to other unsecured creditors. The other party who has this information, or some part of it, is $\mathrm{P}$, since he knows what offer he is making, and may be able to deduce its effect, if it is accepted, on the other creditors. What $\mathrm{P}$ may not know is the likelihood that $\mathrm{R}$ will accept that offer, since $\mathrm{P}$ may not know the value of the next best alternative, and thus the effect on creditors such as D. As with scenario 1, possession of that information lies with $\mathrm{R}$ and is endogenous to the conduct of the insolvency.

\title{
(b) Intra-insolvency trades on generated information
}

In discharging his or her duties, an EA is required, amongst other things, to determine the value of realisable assets and the magnitude of claims against them. In doing this, the EA may generate private information relevant to tradable securities. The key difference between this and the first case is that the EA is less likely to have a monopoly on that information than in the case of endogenous information, although how likely the EA is to have restricted access to that information depends on the extent to which the insolvent corporation has control over another corporation, to which that information relates. On the other hand, the more control the firm has over the subject of the information, the more likely it is to be pulled into the insolvency and out of the actively traded firms on the market. Scenario 3 is an example of such information: 
Scenario 3: $V$, the voluntary administrator of company $C$, has decided to sell off $C$ 's $30 \%$ equity interest in $S$, a related company. It is the largest shareholder in $S . V$ has material, private information related to the financial prospects of $S$.

In this situation, the information has been generated in the course of the EA. The EA's access to it may also be shared by other parties, such as S's directors, controllers, and other substantial shareholders. It may be the case that these other parties came into possession of the information sooner than the EA does. One effect of more widely disseminated private information is that there is a greater likelihood that share prices already reflect the value implications of that information.

\section{(c) Intra-insolvency trades on coincidental information}

During the course of the administration, information may fall into the hands of the EA that the EA does not incur any marginal costs to acquire or produce. The activity that uncovers the information may be costly (eg, investigating the magnitude of the firm's debts), but it is not undertaken with the purpose of generating information. ${ }^{26}$ The information is simply acquired coincidentally. It is the marginal cost of acquisition or production that is the distinction between this and the last categories and there are a large number of contexts in which such information may emerge. For example, they may emerge from the interactions between the EA and the officers. A liquidator may be required to file a report into the circumstances of the insolvency, and will need to speak to the officers as part of that process. Other information may emerge in the course of the process by which debts are proved in the insolvency. To illustrate these examples consider Scenario 4 and 5:

Scenario 4: $V$, the administrator of company $C$, is told by $D$, one of $C$ 's former directors, that he, $D$, is under investigation for fraudulent behaviour in relation to a number of transactions in C's securities that were illegal under market manipulation provisions. $D$ is the $C E O$ of another company, $E$; $C$ has securities in $E$. If $D$ is convicted, he is likely to be incapable of further participating in the management of $E$. $V$ is uncertain when the decision to prosecute will be publicly announced and is considering selling the securities in $E$ ?

Scenario 5: $L$, the liquidator of company $C$, receives a proof of debt by a Norwegian company, $\mathcal{N}$, alleging that $C$ has used internet software that violates intellectual property rights belonging to $\mathcal{N}$. C owns securities in company $E$, which also used the same internet software. $D$ is considering selling securities in $E$ before the information relating to the patent infringement suit becomes generally available?

26 In practice, it may not be entirely easy to distinguish this category from trading on generated information. 
In Scenario 4, the private information relates to the effect on $\mathrm{E}$ of any prosecution of $\mathrm{D}$. In Scenario 5, the private information relates to the effect on $\mathrm{E}$ of the possible patent infringement. Since the EA is in both cases a recipient rather than the generator of the information, the EA is unlikely to have any monopoly over the information. The trading implications of it are likely to be uncertain, unless the EA incurs costs to investigate more attentively. Moreover, the EA may acquire the information rather later in time than other possessors of that information.

\section{(d) Inter-insolvency trades}

Since we have already examined the three types of information which an EA might trade on, it is not necessary to distinguish them again in this context. The hallmark of inter-insolvency trades is that they are based on information emanating from an insolvency other than the one in which the information is used for trade. The scope for such trades is obvious by virtue of the fact that many insolvent corporations will have relatively limited securities holdings, so that the information generated in, or coincidental or endogenous to the insolvency, cannot be used in relation to that security. Given, however, that the EA is likely to have an involvement with other insolvencies at the same time, there may therefore be other opportunities to use that information in other contexts. These are suggestive of misappropriation theory possibilities. We may develop a sixth scenario, which is based on an adaptation of scenario 1 involving endogenous information.

\section{Scenario 6: $L$, a liquidator of company $C$ is considering initiating a suit on behalf of $C$ against company $D$ alleging misleading and deceptive conduct. Company $C$ does not hold stock in $D$, but company $E$, of which $L$ is also the liquidator does hold stock in $D$. $L$ trades $E$ 's stock before information regarding the suit of $C$ against $D$ is publicly available.}

Similar adaptations are possible with the other earlier examples. In some of these cases, the trade would not be thought to impose harm on the company the insolvency of which caused the information to be generated. But there are clear exceptions, in those situations where there is actual moral hazard. The first relates to information about a firm's insolvency before it is publicly known. Scenario 7 is an illustration involving a company that seeks advice in relation to a reconstruction before its insolvency problems are publicly known. The concern is that insider trading may cause that information to come to light, doing harm to the company seeking the advice.

Scenario 7: $L$ is a registered liquidator and offers advice in relation to financial reconstructions. Company $C$ seeks advice in relation to financial reconstruction. Company $D$, which holds securities in company $C$, commences winding up and $L$ is appointed the administrator. $L$ would like to sell D's securities in $C$. 
The other example of a classic conflict of interest is where the EA engages in some form of "front running" on behalf of an insolvent corporation in precedence to the corporation whose insolvency gave rise to the information. Hence, we may vary the sixth scenario as in Scenario 8 to illustrate this.

\section{Scenario 8: $L$, a liquidator of company $C$ is considering initiating a suit on behalf of $C$ against company $D$ alleging misleading and deceptive conduct. Company $C$ holds stock in $D$, as does company $E$, of which $L$ is also the liquidator. $L$ trades $E$ 's stock first, and then D's stock next, before information regarding the suit of $C$ against $D$ is publicly available.}

In the next section we revisit what is described above as a potential third dimension of informed trades by EAs - the communication of information to others, or the procuring of trades by them. This is closely related to inter-insolvency trades, because of the severing of the "proprietary" connection between the persons on whose behalf the trade is undertaken and the firm whose insolvency was the context for the origination of the information.

\section{(e) Procuring and Communication}

The practice of tipping is a very frequent issue arising in the context of insider trading. It arises in part because of the inability (either because of transaction costs or because a person's trades are especially closely monitored) of a single person to exploit all of the trading opportunities associated with private information, and may also arise in a context of repeat dealings in which information is exchanged in the expectation of other benefits.

The persons most likely to be tipped in relation to the information are the creditors of the insolvent corporation. In the United States, for example, this issue is particularly acute in the context of insider trading by members of creditors' committees in insolvent firms. That is obviously a particular issue where the creditors are financial institutions, likely to have a wide range of equity investments under management. In the Anglo-Australian context, where a receiver is appointed under contract by a secured creditor, there is a particular concern associated with the relay of information by the receiver to the secured creditor. Scenario 9 illustrates.

Scenario 9: $R$, a receiver of company $C$, appointed by bank $B$ under a floating charge, has come into possession of private information gleaned from the conduct of the receivership regarding the securities of company $D$. $C$ does not own securities in $D$, but $B$ owns put options on D's shares. May $R$ communicate that information to the officers of B prior to that information becoming generally available? 


\section{G. The Legal Strugture of Informed Trading by External Administrators}

\section{Introduction}

In Section A of this article we examined the different approaches to insider trading liability that are employed internationally. The purpose of this section is to examine, in light of these different legal regimes, what issues are likely to arise in the context of the forms of insider trading that we identified in Section B. Although our focus is primarily on insider trading liability per se, there are other legal issues, such as fiduciary duties, in some of these cases. We should note that our focus is intended to be a general examination of issues, rather than at a more detailed doctrinal analysis of each.

\section{Intra-insolvency trades on endogenous information}

The only incidence of a proscription of trading in these cases would seem to arise under third-generation, Australian-style prohibitions on informed trading. Here the exemption for liquidators excuses the trade in Scenario 1, but there is no similar exemption for receivers in Scenario 2. The American and English approaches would not seem to proscribe the trade. In the case of the American system, there is simply no misappropriation. The information is not being used deceptively or in breach of any confidence or fiduciary duty. On the contrary, it is being used in the context it originates, presumably for the best interests of the residual claimants (now, the creditors) of the firm. In using the information to realise the value of assets for the highest value, the EA is likely to be acting in a manner that is consistent with the EA's fiduciary duty, or at least consistently with his contractual obligations in cases of receivership. Similar comments apply to the English system, since by trading on information relating to the company on the company's account, the EA simply does not trigger any of the definitions of it as an "insider". These results would seem to apply equally to both Scenarios 1 and 2 .

\section{Intra-insolvency trades on generated information}

The situation in relation to information that the EA generates in the course of conducting the administration would be expected to stand in a similar category to intra-insolvency trades on endogenous information. The information is generated in the course of the administration, so the application of the misappropriation theory would be expected to give practically identical conclusions in relation to this matter. Likewise, the results for the second and third generation of statutory insider trading laws would also not be expected to apply differently. 
The reader may recall that Scenario 3, illustrating this category of information, involved information that related to a corporation in which the insolvent firm had a controlling interest. Such cases are particularly likely to arise in the context of intra-insolvency trades on generated information, since the insolvent firm is more likely to have prior access to this information than other people in the market. Consistent with this possibility, attempting to trade those securities without revealing private information may not actually be possible.

\section{Intra-insolvency trades on coincidental information}

The possibility that a legal prohibition applies to intra-insolvency trades on coincidental information is somewhat greater than for the two categories above. In the first two situations, the information in question was generated by the EA or within the context of the external administration. In this third situation, by contrast, the EA will usually receive the information from another person directly, or based upon an interaction with that other person. The question that then arises is whether or not trading on that information would be inconsistent with the purposes for which the information was communicated. Put in a slightly different way, are there any limits on the EA's property rights in the information that has been provided to him? In particular, are there some uses of that information which are permitted or are there some which are not? Clearly, in the context of the misappropriation theory, the determination of the possible uses of a certain piece of information will determine the nature of the EA's fiduciary duty.

To apply this to Scenarios 4 and 5, is there any possible basis for distinguishing the two cases? On the one hand, the information in relation to a proof of debt has to be made known to the EA - it goes to a fundamental part of the insolvency for debts to be advised to the EA. On the other hand, information learnt more coincidentally ranks in a different situation. In Scenario 5, for example, the information relating to the offences committed by the director may be thought to have an important connection to an EA's responsibility as an officer of the court to investigate potential offences committed by directors of the firm. The difference may be that information learnt when acting as an officer of the court may be regarded as relevantly different to information learnt as part of the mainstream administration. The former information is imparted only for relay to the regulatory authorities; the latter is not. Australian law is relevant in this respect since it provides that communication of insider information is itself an offence, although it excuses communications which occur in circumstances where the person receiving the information was not expected to trade on it or to procure others to do so.

A clearer situation might arise in a context where a former director relayed information concerning a corporation that had nothing to do with any offence he or she had committed - that the EA had no real reason to know or discover. Particularly where the director acquired that information in the context of service 
on another board, any communication to the EA would arguably be tainted as being in breach of a fiduciary duty or duty regarding confidential information. Any attempt by the EA to use that information would presumably be treated in the same way. Thus, the key legal issue would be thought to focus not on the EA but on the source and the context of the private information.

\section{Inter-insolvency trades}

In Section B, we argued that some inter-insolvency trades could prejudice the interests of the firm that generated the information, whereas others would not be expected to do so directly. However, the need to prove an element of loss has never been regarded as necessary for a breach of fiduciary duty. All that is necessary is some action which is motivated by interests other than those which the fiduciary is obliged to protect. It would seem reasonably straightforward that an interinsolvency trade, such as those in Scenarios 6 and 7, would be actionable under the misappropriation theory. Indeed, in the case of an inter-insolvency trade, there would arguably be, in some cases, a double misappropriation - a breach of duty in relation to both the original source of the information, and a breach in relation to the insolvent company in the administration of the insolvency of which that information was learnt.

In much the same way, it would seem likely that inter-insolvency trades would constitute prohibited actions by a primary insider, at least in relation to endogenous and generated information, and possibly also as a secondary insider in the case of the more adventitiously acquired forms of coincidental information.

In this regard, however, the Australian approach to insider trading in interinsolvency trades by liquidators would appear to be protected by the exemption provision for liquidators. That is not to say that this provision would constitute a total dispensation of liability. There is still scope for liability for breach of fiduciary duty, as well as the scope for liability under statutory provisions applicable to officers (which includes external administrators) which reinforce general law duties in the context of the "improper" use of information acquired by virtue of the officers' position. ${ }^{27}$ In situations such as Scenarios 7 and 8, where there may be actual damage inflicted, some form of action for damages or equitable compensation would seem to also be open.

\section{Procuring and Communication}

The likelihood of some form of prohibition is very high in the context of the procuring and communication offences. Liability is common here, for both the tipper or for the tippee. In the United States, insiders are liable for disclosing inside information to recipients where the disclosure breaches a fiduciary or like

27 Corporations Act 2001 ss 182, 183. 
duty owed by the tipper either to the company whose securities are traded or to the owner of the inside information. ${ }^{28}$ The United Kingdom approach is similar. Communication of insider information by primary and secondary insiders is prohibited unless it takes place in the proper performance of the communicator's employment or office. ${ }^{29}$ As with Australian law, there is also a defence where the person to whom the information is communicated is not expected to trade on that information, or that any trade would not result in any profit. ${ }^{30}$ There may be overlapping remedies in this context as well, such as an action for breach of confidence.

\section{Syntheses}

What is apparent is that there are important variations between the three different generations of legal regimes in how they respond to these different types of trades. In order to capture these differences, we redraw Table I for each of the principal regimes. It is observed that the US and UK models (Tables II and III) produce roughly similar results, in terms of the trades proscribed. That is, interinsolvency trades are seen to be unlawful in both systems whereas intra-insolvency trades are not (except for those involving coincidental information). By contrast, the Australian system (Table IV) reaches very different results, which are strikingly invariant with respect to trade type.

Table II: Treatment of Informed Trades under the US Model

\begin{tabular}{lll}
\hline & Intra-insolvency Trades & Inter-insolvency Trades \\
\hline Endogenous information & No liability & Misappropriation \\
Generated information & No liability & Misappropriation \\
Coincidental information & Potential misappropriation & Misappropriation \\
& liability if used in breach of & \\
& confidence or duty & \\
\hline
\end{tabular}

Table III: Treatment of Informed Trades under the UK Model

\begin{tabular}{lll}
\hline & Intra-insolvency Trades & Inter-insolvency Trades \\
\hline $\begin{array}{ll}\text { Endogenous information } \\
\text { Generated information }\end{array}$ & No liability & Liability as a primary insider \\
Coincidental information & Potential liability as a secondary & $\begin{array}{l}\text { Liability as a primary insider } \\
\text { Liability as a primary and } \\
\text { secondary insider }\end{array}$ \\
& & \\
\hline
\end{tabular}

28 D Langevoort, Insider Trading: Regulation, Enforcement and Prevention (West Group) (looseleaf) s 4.06.

29 Criminal fustice Act 1993 s 52.

30 Ibid, s 53. 
Table IV: Treatment of Informed Trades under the Australian Model

\begin{tabular}{lll}
\hline & Intra-insolvency Trades & Inter-insolvency Trades \\
\hline Endogenous information & No liability for liquidator, & $\begin{array}{l}\text { No liability for liquidator, TIB. } \\
\text { Receiver, VA liable } \\
\text { TIB. Receiver, VA liable }\end{array}$ \\
Generated information & No liability for liquidator, & $\begin{array}{l}\text { No liability for liquidator, TIB. } \\
\text { TIB. Receiver, VA liable }\end{array}$ \\
& No liability for liquidator, TIB. & No liability for liquidator, TIB. \\
Coincidental information & Receiver, VA liable & Receiver, VA liable
\end{tabular}

The question that arises, which we examine in the following section, is which of these patterns of results is most consistent with the results that would be reached by the a priori application of economic analysis to each of the categories of insider trading.

\section{An Egonomic Analysis of Informed Trading By External Administrators}

In this section, we review some of the main policy arguments put in relation to insider trading, and which have been proposed as justifying particular balances between permission and prohibition. We conclude in general that these have little to offer in permitting or prohibiting insider trading. We then review other arguments more particular to insider trading by EAs. Finally, we review our taxonomy of cases and how these arguments might be brought to bear on the case-types.

\section{Principal Policy Arguments in Insider Trading}

In this section, we consider three important policy arguments in relation to insider trading. The first relates to the theory that the law imposes a prohibition where a trade is based on an informational advantage that is not susceptible of being eroded by other traders, and a permission where that advantage is in some sense replicable. The second, which is related to the first, theorises that the law on insider trading optimises, or at least should optimise, the incentive to create new information, and to bring this information to the market. The third, which is more a group of arguments than a single argument, are those that permit certain forms of insider trading and prohibits others in the interests of the equityholders of the firm. We consider each of these seriatim.

\section{(a) Erodability}

One of the principal policy arguments that defines an agenda for insider trading regulation is the claim that it is unfair for parties to trade on "unerodable" informational 
advantages, especially those which might arise from a person's position in a firm or other privileges connected to that firm. This theory holds that such advantages cannot be matched or overcome by even the most diligent analysts. The argument is best put as a claim in relation to fairness or equity because using those advantages is unfair to those who do not have those advantages. It is often a short step from that claim to the argument that permitting trading on such advantages would diminish the confidence of investors who do not have informational advantages to enter and trade in the market. One of the most persuasive recasting of such a theory in economic terms is Nick Georgakopoulos's use of the theory of market microstructure to analyse the effect on bid/ask spreads and liquidity of monopolies on information, and its use for "strategic" informed trading. ${ }^{31}$ Georgakopoulos shows that investors trade less often (depriving the market of liquidity) where they perceive that an insider, or a group of insiders acting in concert, can trade strategically on insider information.

The theory of erodability is vulnerable to various criticisms. Ian Ayres and Stephen Choi point out there is little or no reason to believe that trading on an erodable advantage necessarily increases social welfare, because of the risk of either excessive investment or underinvestment in search costs. Likewise, trading on an unerodable advantage might increase social welfare, to the extent that it leads to efficiency gains in more accurate share prices. Ayres and Choi's claim is that these possibilities require a contractible approach to informed trading law which essentially endows the firm with the power to decide whether informed outsider or informed insider trading should be permitted.

What light does the erodability of an informational advantage shed on insider trading by the EA? In truth, very little. First, in relation to intra-insolvency trades on endogenous information we find that the case for a prohibition is here perhaps at its strongest, since the EA has access to such endogenous information solely by virtue of his office. The EA will monopolise this information until his decisions become publicly announced. Thus, in theory, the case for prohibiting a trade on this information should be quite strong. Yet as we have seen such trades are the most likely to survive legal challenges.

Secondly, in relation to intra-insolvency trades on generated information, the application of the erodability theory depends in part on the information itself. As noted above, the situation where the information relates to the value of a shareholding in a company over which the company has control is one where the informational advantage is likely to be unerodable. In general, the informational advantage would be expected to depend on how much control the insolvent firm has over the company whose securities the EA trades.

Thirdly, in relation to intra-insolvency trades on coincidental information, the informational advantage is inherently likely to be more widely available than

31 See Nicholas L Georgakopoulos, "Insider Trading as a Transactional Cost: A Market Microstructure Justification and Optimization of Insider Trading Regulation" (1993) 26 Connecticut Law Review 1. 
endogenous or generated information. That is particularly true in a case like Scenario 5, where information about the overlapping intellectual property rights are both in the public domain. On the other hand, where the information is passed on by another person with an unerodable informational advantage, as is true in Scenario 4, one might expect in some cases a prohibition to apply to any trade on the information by the EA, analogously to a tippee.

How do these results change in inter-insolvency trades? One would expect that the results do not change, since the informational advantage remains substantially as it was before. Prohibitions would persist for endogenous information, generated information in relation to controlled companies, and information derived from tippers with access to insider information. On this analysis, then, erodability is incapable of explaining the varied legal results that we observed in Section C. To see this in tabular form, observe Table $\mathrm{V}$, and compare it to Tables II to IV above. We can see it does not explain any of the patterns in any of the systems.

Table V: How Erodability Should Explain a Pattern of Regulation ${ }^{32}$

\begin{tabular}{|c|c|c|}
\hline & Intra-insolvency Trades & Inter-insolvency Trades \\
\hline Endogenous information & Strong case & Strong case \\
\hline Generated information & $\uparrow$ & $\uparrow$ \\
\hline Coincidental information & Weak case & Weak case \\
\hline
\end{tabular}

\section{(b) Creation of New Information}

Related to the theory of erodable information advantages is the claim that providing scope for informed trading encourages the creation of new information, which, when disclosed or traded on, adds to the accuracy of stock prices. This theory is consistent with the misappropriation theory, to the extent that it recognises some degree of property rights (in the sense of excludability) associated with the creation of new information.

However, this premise is unlikely to provide much scope for permitting insider trading in cases involving EAs. A great deal of the information that we have seen will be inframarginal to any law regulating informed trading. In other words, that information will be created or acquired anyway, as a by-product of the EA itself. Certainly, that is true of endogenous information and much coincidental information. But it is less than wholly clear that the inframarginality of these forms of information is actually a ground for prohibiting trade. Since the marginal social cost of production is zero, the case for permitting trade depends on the balance between the other benefits associated with permitting trade (such as increased

32 In this and the following tables, the strength of the case referred to is the one for a prohibition, not for a permission. Thus, a weak case is equivalent to an argument for such a trade to be permitted. 
accuracy of stock prices, or decreasing the agency costs associated with the appointment of an EA) and any attendant social costs. ${ }^{33}$

Generated information stands in a slightly different category to endogenous and coincidental information. The EA incurs costs to generate information in order to determine the most expeditious form of realisation, and to set decision rules in relation to the trades that should or should not be made. Thus, to allow the EA to trade on such information preserves the incentive to create such information. Generating this information ought to make the residual claimants of the insolvent firm (the creditors) better off, to the extent that the cost of generating this information is presumably less than the private benefit arising from the returns from beneficial realisations of the securities. However, that is not the dispositive inquiry from an efficiency perspective, because the private benefit to the residual claimants of the insolvent firm will be exactly offset by the uninformed traders in the securities the EA has traded. The question, rather, turns on the comparison between the cost of producing this information, and the social benefits from its production. This, too, is not very clear at the abstract level. So the strength of the case for permitting trades on generated information is theoretically no clearer than it is for permitting trades on endogenous information.

As with the question of informational advantage erodability, it is by no means clear that the information-production incentive effect of the law provides any insight into this area, either. It provides relatively little insight, also, into the distinction between intra- and inter-insolvency trades. Arguably, it provides a justification for inter-insolvency trades to the extent that a prohibition of these trades preclude an EA from preferring the creditors of insolvencies other than the one in the context of which the information is generated. ${ }^{34}$ However, that argument does not seem persuasive, since the purpose of such a prohibition could just as easily be served by a "front-running"-type ban on trading the securities of other insolvent firms ahead of those owned by the corporation in whose insolvency the information was generated. In addition, permitting inter-insolvency trades responds to a problem that the incentive for an EA to use any information depends on the EA holding the appropriate securities that can be traded (in effect, sold) the scope for trading between insolvencies actually allows the incentive effect to operate. In other words, a law that is intended to motivate information production cannot have any effect unless securities exist and inter-insolvency trades effectively expand that pool. An argument could thus be made for allowing inter-insolvency

33 It is not clear whether there are any costs. These costs would be thought to arise in the case of genuine insider trading, because of the risk that insiders may alter the production or investment decisions of the firm in order to create profitable trading opportunities (for example, by increasing risk). These would be thought to fewer in this outsider-type situation, although there may be some situations where the insolvent firm has control over the corporation whose securities are traded. (see section $(f))$.

34 For example, the liquidator of firm A who generated private information about the securities of company $\mathrm{Z}$ would be required to trade the securities of firm $\mathrm{A}$ before those of $\mathrm{B}, \mathrm{C}, \mathrm{D}, \ldots \mathcal{N}$. That would preserve priority for the creditors who "subsidise" the production of this information. 
trades to the extent that each firm would be willing to subsidise the production of information to the extent it would increase the chance of gainful trades on any securities it holds, rather than just those that possessed private information. ${ }^{35}$ So, Table VI again shows a pattern that is not consistent with any of Tables II to IV.

\section{Table VI: How Information Production Should Explain a Pattern of Regulation}

\begin{tabular}{|c|c|c|}
\hline & Intra-insolvency Trades & Inter-insolvency Trades \\
\hline Endogenous information & Ambiguous case (inframarginal) & Ambiguous case (inframarginal) \\
\hline Generated information & Moderate case & Moderate case \\
\hline Coincidental information & Ambiguous case (inframarginal) & Ambiguous case (inframarginal) \\
\hline
\end{tabular}

\section{(c) The Interests of Shareholders}

Much of the economic analysis of insider trading, beginning with Henry Manne's famous analysis, ${ }^{36}$ has developed various arguments why insider trading might actually be in the best interests of the shareholders of the corporation. ${ }^{37}$ This would enable a permission of insider trading to be justified as a hypothetical bargain, consistently with the dominant normative heuristic used in corporate law. On the other hand, there are contrary arguments and below we consider several of these issues for their relevance to trades by EAs. Some of the most discussed issues (such as the effect of informed trading by managers on management incentives in an incomplete contracting environment ${ }^{38}$ ) are not relevant, because they are premised on a trade by an insider, not just an informed trade.

As a preliminary matter, we may note that an "interests of the shareholders" argument used in the context of informed trading by EAs is immediately complicated by two things. First, which shareholders are we referring to? The shareholders of the firm in whose securities the EA trades, or the shareholders (or their successors as residual claims, the creditors) of the now-insolvent firm? This is the key question associated with any outsider trading situation, as Ayres and Choi recognise. In general, the former group of shareholders is likely to internalise a wider range of the costs and benefits of informed trading. However, as we shall see in this context, these arguments tend to divide between contexts. The first argument relates to the interests in the traded firm, but the following ones relate to interests in the insolvent firm.

35 On the other hand, that contract might not be agreed to because of the possibility it would favour firms which hold substantial shareholdings - a side payment would be required at the very least to compensate these firms that expect to be the net losers from the bargain.

36 Manne, above $\mathrm{n}$.

37 D Carlton and D Fischel, "The Regulation of Insider Trading”, [1983] Stanford Law Review 35 857-95.

38 Darren T Roulstone, "The Relation Between Insider-Trading Restrictions and Executive Compensation" (2003) 15 fournal of Accounting Research 3, 525-551. 


\section{(d) Stock-price accuracy}

One of the principal arguments for insider trading is that it has the effect of increasing the price efficiency of the capital market. This occurs when market analysts translate the signal lying behind buy and sell orders from insiders. The extent of the stock-price effect from insider trading depends in large part upon how many parties have the information and how liquid the market in the stock is. These factors determine the extent to which the insider or insiders can trade smaller parcels of the stock more frequently in a strategic manner designed to extract the maximum rent from the private information. ${ }^{39}$ Accuracy is generally in the interests of shareholders, because of the value of stock prices as a means of determining the quality of management, and in order to make better consumption, saving and investment decisions.

Stock-price accuracy is unlikely to offer much persuasive justification for permitting informed trading by EAs. The reasons are relatively simple. First, if the EA turns up "good news", there are likely to be no trades he can engage in on the basis of that information. He is a seller, not a buyer. His best response will therefore be to do nothing until the information becomes public. Those actions are unlikely to contribute anything to price efficiency. Secondly, if the EA turns up "bad news", the extent of the stock price reaction to any trade he undertakes is likely to depend on the size of the parcel he has to trade. So, trading by the EA is likely to speed up price falls and perhaps retard price rises. It is thus unclear on the directional relationships and we have not drawn a Table for this heading because it is not obvious how this argument differs at all for any of the trade types.

\section{(e) Delaying Disclosures}

By contrast to the first argument regarding stock-price efficiency, a counterargument directed against insider trading is that it encourages managers to defer disclosures which would move the share price in order to give them an opportunity to trade first. ${ }^{40}$ This argument has some relevance to the external administration context, but only where the EA is under some form of obligation to make disclosures. The principal instances where this may be a problem is in a case like Scenario 1 and 2, related to endogenous information, which the EA will disclose publicly at some future point. By contrast, the EA would not seem to have any generic obligations to disclose publicly most of the generated information relevant to asset values (although a mandatory disclosure obligation is possible in some situations), or his coincidental information. So there is a possible case for prohibiting trades on endogenous information. By contrast, this argument may have its most telling criticism against inter-insolvency trades, since the scope for delay is probably greatest in those situations where more than one trade is contemplated. This is reflected in Table VII:

39 Nicholas L Georgakopoulos, "Insider Trading as a Transactional Cost: A Market Microstructure Justification and Optimization of Insider Trading Regulation" (1993) 26 Connecticut Law Review 1. 
Table VII: How Disclosure Delay Should Explain a Pattern of Regulation

\begin{tabular}{llll}
\hline & Intra-insolvency Trades & Inter-insolvency Trades \\
\hline Endogenous information & Strong case & $\rightarrow$ & Strongest case \\
Generated information & Moderate case & $\rightarrow$ & Strong case \\
Coincidental information & Weakest case & $\rightarrow$ & Weak case \\
\hline
\end{tabular}

\section{(f) Changing Investments}

It has been argued that one of the reasons why one might want to prohibit insider trading is its effect on the insiders who decide investment policy of the firm. ${ }^{41}$ For example, the insider might specifically chase risks whether or not these risks added value to the firm in order to create both upside and downside opportunities for trade. This point may initially seem to have little application to the EA. We would need to identify a situation where the EA deals with the assets in such a way that it created a profitable insider trading opportunity in spite of its effect on the assets. However, since we are examining a situation where the EA is trading on his own account, that does not appear to be a particular concern. The EA is an outsider trading the securities of firms whose assets he does not control, which limits most of the situations where this might occur.

The only way in which this might occur is if the EA takes decisions in the administration that cause the value of other companies to fall, as for example in the situation with insider trading on endogenous information. Scenario 2 is an example. However, in these situations, the EA is simply trading in advance of a loss that would otherwise be sustained by the estate. Moreover, as will be recalled, in Scenario 2, the decision to sell the assets increased the welfare of the secured creditors; it did not decrease the value of the assets themselves. The EA will never choose to decrease the value of the assets in order to generate private information to trade on, since the effect on the value of the assets will always exceed the effect on the value of the securities of other firms. ${ }^{42}$ This is unlike the paradigm insider trading situation where the insider does not internalise the full social costs of the changed production-investment opportunities.

\section{(g) Conclusion}

To conclude, the principal economic arguments that have been arrayed for and against insider trading, or for and against particular distinctions between what is

${ }^{40}$ K Scott, "Insider Trading: Rule 10b-5, Disclosure and Corporate Privacy" (1980) 9 Journal of Legal Studies 801 at 817-18.

41 R Haft, "The Effect of Insider Trading Rules on the Internal Efficiency of the Large Corporation" (1982) 80 Michigan Law Review 1051.

42 This is because no firm ever internalises more than $100 \%$ of the effect on the other firm, and often internalises only a very small fraction. 
permissible and what is prohibited, seem to offer few clear conclusions. Similarly, they seem to explain very little of the current operation of the prohibitions on insider trading, observed internationally, applied to the situation of interest to us. It is therefore appropriate to move on to consider a series of arguments that respond more specifically to the practical circumstances in which informed trading by an EA is likely to arise.

\section{Arguments Specific to the EA Gontext}

In the last section, we examined how the context of trading on private information by the EA can undercut or render irrelevant the normative thrust of any particular policy argument for the permission or prohibition of insider trading. In this section, we review these points in more detail. We find in this context a more specific set of justifications for exempting informed trading by EAs. In the following section 3, we examine these arguments in the context of the Scenarios introduced in section B.

\section{(a) Identifying Insider Trading}

The first operational consideration relates to the difficulty of distinguishing trading that is based on private information from trading where that information is not influenced by the possession of information. As we have seen, the principal responsibility of an EA usually involves the sale of assets. This is the case in each of the principal approaches to insolvency and in a formal liquidation the EA has a duty to take possession of the company's assets and realise them. A slightly different dynamic arises in a reconstruction of some form, whether of the Chapter 11 variety in the United States, or of the administration procedures in Anglo-Australian law. Prior to the creditor's meeting where the proposed re-arrangement is voted on, it is not the external administrator's job to liquidate the assets of the company. However, the administrator does have the power to sell assets and it would not be unusual or surprising if he or she decided to sell assets, such as marketable securities in other companies, that are not required for the conduct of the business should there be a decision made to reorganise the business. The final insolvency situation is the "privatised" variety best known to Anglo-Australian law in which a receiver is appointed under a floating charge. The receiver's duty in this case is to deal with the assets in a manner that enables the creditor to maximise the value of his or her security in order to discharge the underlying debt. That usually involves the sale of assets, either on a going concern or piecemeal basis. Should it be more profitable to attempt to reorganise or turn the business around those steps would usually be undertaken prior to the adoption of the more extreme "endgame" step of appointing a receiver. ${ }^{43}$

${ }^{43}$ J Franks and O Sussman, "Resolving Financial Distress By Way of a Contract: An Empirical Study of Small UK Companies" unpublished paper. 
Because the sale of assets is either the dominant responsibility or a legitimate power of the EA, the EA will not, and cannot be expected to, follow a "hold" strategy in relation to marketable securities even in the intermediate term. In other words, they must sell relatively soon after appointment. If the EA will sell at some time, it may be very difficult to tell whether the timing of that decision was motivated by information or whether it was reached by independent reasoning. It may not be difficult to lay a "paper trail" in order to demonstrate that the decision was reached before the information came into its possession. If a plaintiff or a prosecutor finds it difficult to identify which of these trades is proscribed, and which is not, the costs associated with the high incidence of Type I errors (permitting informed trading) and Type II errors (prohibited uninformed trading) will justify a more general permission of trading. This provides some justification for the carte blanche exemption provided in Australian law, but does not explain why one would differentiate between a liquidator versus a receiver or administrator.

\section{(b) The Scope for Insider Trading Liability}

The second point also derives from the fact that the only trade an EA will enter will be a sale of an existing holding of securities. The other possible trades - short sales and purchases - are most unlikely to be observed by an EA acting intra vires. It follows therefore that where the EA possesses insider information, the EA can only use it:

(a) by deciding to sell (where the information is "bad", suggesting the securities are overpriced) or by deciding not to sell (where the information is "good", suggesting the securities are underpriced); and

(b) in relation to the securities of other companies owned by the company under administration, since the market in that company's own securities is likely to have come to an end.

These considerations suggest that the scope for insider trading is limited and nonsystemic. To impose liability for trading by the EA would often be capricious. This is because a decision not to sell, or to postpone a sale (in the advent of good news) is not prohibited by the legislation, whereas a decision to sell in anticipation of bad news would be prohibited. As we can see from condition (a), decisions not to sell or to postpone selling will be expected to constitute approximately half of the cases where the EA is able to make use of private information (purchases and short sales being impossible). ${ }^{44}$ This is unlike the situation that prevails for other traders where a decision to purchase securities, buy call options, or sell put options, on the revelation of good news will always dominate in the sense they produce a higher payoff than a decision to postpone a sale. In these situations, it makes sense not to

44 This proceeds from the assumption that the EA is as equally as likely to come into possession of goods news as bad news. 
proscribe postponement. That logic, however, does not apply to EAs. Moreover, if we compare the two forms where the EA can make use of insider information, the decision to sell may contribute to market efficiency to the extent that the size of the trade permits an effect on price, whereas a decision not to sell cannot of course have that effect.

This argument has been made in other parts of the literature - that decisions not to trade, based on private information, are not proscribed, even though they may well constitute a dominant use of private information. ${ }^{45}$ That argument has been criticised by Jesse Fried. ${ }^{46}$ Fried argues that decisions not to trade are qualitatively different from decisions to trade. Where there is a decision not to trade, the insider simply earns the market return on the equity, like uninformed traders taken as a whole, even though he avoids a loss. By contrast, where there is a decision to trade, the insider earns a positive abnormal return, at the expense of uninformed traders. Thus, there is a cost to uninformed trade that is not paralleled in the situation of informed non-trade.

Although a cogent argument, it needs to be qualified for the EA context: namely that the law encourages EAs to realise assets, rather than encouraging them not to realise them. Thus, to proscribe realisation based on private information, but to permit holding strategies similarly based, is inconsistent with the essential nature of an EA's role. This is unlike non-insolvency contexts, where there is no reason to be indifferent between realisation and holding.

Once more, these considerations seem to support an approach which provides a generalised exemption, at least for intra-insolvency trades, but which does not discriminate between liquidations and other forms of administration.

\section{(c) Reputational and market effects}

The market incentives applying to the EA discourage socially undesirable forms of insider trading. It would be preferable to leave the regulation of these trades to these market incentives. On one hand, the EA internalises little or any of the outcome from the trade. Any informational rents flow to creditors. This outcome immediately attenuates the EA's incentive to trade. On the other hand, the EA has an incentive to maintain a reputation for demonstrating professional ethics. Although insider trading may be difficult to detect in general, trades by the EA will be relatively easy to detect because the EA is obliged to keep books and records, which may be examined by contributories and creditors. ${ }^{47}$ The market will be able to infer, ex post, those trades which were based on private information. The EA therefore has an incentive to engage only in those trades which do not negatively affect his reputation. Because the EA's reputation ought to be consonant with

\footnotetext{
45 See the references cited in $\mathrm{n} 20$ above.

46 Fried, above $\mathrm{n}$

47 Corporations Act 2001 s 531.
} 
social welfare, the market incentives are likely to be sufficiently effective that regulation is unnecessary.

The extent to which we can rely on the EA's reputation as a self-enforcing device in this area is reinforced by the EA's general law duties. Those duties encourage the EA to use private information consistently with the best interests of the creditors, rather than based on the interests of other parties, or the EA's own interests, or in some other manner involving overreaching. These legal duties restrict any residual incentive of the EA to act in a manner that reputational considerations might be thought to discourage, because of the magnitude of a oneoff gain.

This factor provides the strongest explanation for the shape of the US-UK bias against inter-insolvency trades, and perhaps also against the use of coincidental information in intra-insolvency trades.

Table VII: How Reputation Should Explain a Pattern of Regulation

\begin{tabular}{llll}
\hline & Intra-insolvency Trades & Inter-insolvency Trades \\
\hline Endogenous information & Weak case & $\rightarrow$ & Strong case \\
Generated information & Weak case & $\rightarrow$ & Strong case \\
Coincidental information & Moderate case & $\rightarrow$ & Strongest case \\
\hline
\end{tabular}

In the following Section 3, we consider these issues in the context of the more specifically defined scenarios of insider trading by an EA that would, in the absence of an exemption, be prohibited by the insider trading provisions. We find, in general on closer examination, that the case for excluding EAs from the terms of the legislation are reinforced.

\section{Analysis of Insider Trading by External Administrators}

(a) Intra-insolvency trades on endogenous information

Scenario 1: L, a liquidator of company $C$ is considering initiating a suit against company $D$ alleging misleading and deceptive conduct. Company $C$ holds stock in D. L must decide the time at which to sell securities in D before announcing publicly that he will sue D?

In this case, the private information is that $\mathrm{L}$ will bring a suit on behalf of $\mathrm{C}$ against D. As we have seen, in Australian law, although prima facie prohibited, the trade would not be prohibited by the insider trading laws in the UK and the US and would be permitted by the general exemption.

The clue which helps to reveal the appropriateness of this resolution is to acknowledge that it is L's fiduciary duty to maximise the value of the estate of company $\mathrm{C}$, on behalf of its creditors. In this case, then, we may suggest that the 
fiduciary duty is consistent with the non-negative effect of this trade on the reputational capital of the liquidator. That duty applies to his or her decisions both to litigate and to realise the value of the securities in D. Let us assume that the decision occurs in the context of a three-period model. At $t_{0}$, L decides whether or not to litigate, based on an expectation that $\mathrm{C}$ will succeed in recovering damages, $A$, with probability $p$. At $t_{0}$, the market valuation of $\mathrm{D}$ is $V$, and $\mathrm{C}$ owns some percentage, $g$, of $\mathrm{D}$. At $t_{1}$, L commences litigation, which is publicly observable by the market. At $t_{2}$, the litigation is resolved, and $\mathrm{L}$ either recovers $A$ or nothing. For convenience, we have assumed away litigation costs. Figure 1 demonstrates the payoffs to $\mathrm{C}$ in each period (from both the sale and the lawsuit), should the sale occur in that period:

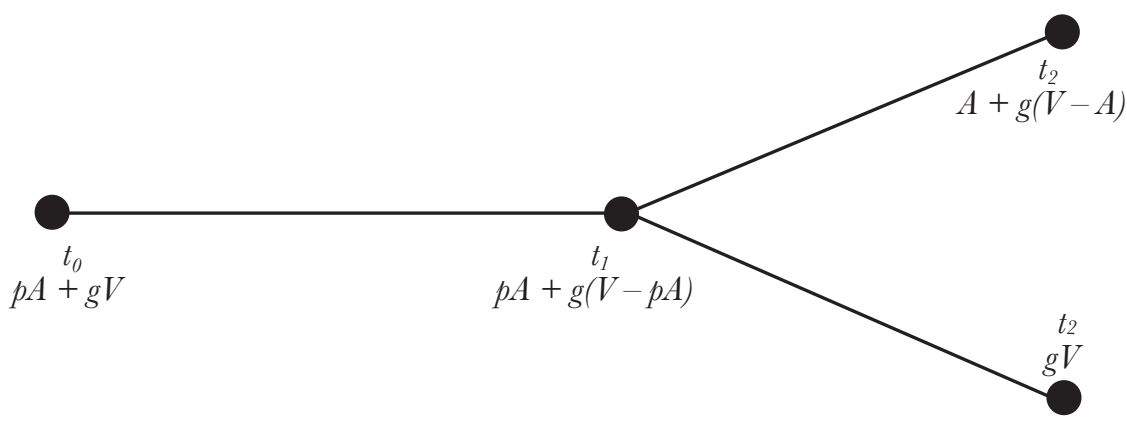

Fig. 1. Payoffs to the Company

It is clear that the value of $\mathrm{C}$ is maximised by selling at $t_{0}$, given the reduction in the value of $\mathrm{D}$, after the litigation is announced. We would argue that it is not "unfair" for L to take this course of action. ${ }^{48}$ It is arguable that the optimum would be for $\mathrm{L}$ to sell the securities before he decided whether or not to commence the litigation in order that the value of the shares do not affect L's decision. However, there is no practical difference in outcome between selling before the decision is made, and selling before the decision becomes public knowledge. In both cases, the liquidator sells at the then extant market price, and expects to receive $p A$. It follows that there should be no difference in legal treatment. That result also suggests that market efficiency may not be substantially affected by selling prior to the announcement. Information related to the possibility of a suit would often be known to parties associated with $\mathrm{D}$, so the market price may already reflect the likelihood of the suit. We have seen some of the arguments against this proposi-

48 On the contrary, if the liquidator has a bona fide belief that he or she has suffered loss at the hands of XYZ, it would be entirely unfair for the creditors of ABC to suffer further loss by the reduction in the value of the stock. 
tion, too. The information advantage is unerodable, which suggests the trade should be prohibited, but on the other hand, there is a possible argument for motivating the production of this information (although endogenous information is inframarginal) as we saw. So these two points tend to cancel each other out.

This conclusion is reinforced if we move away from the simplified three period model to a world of continuous time, in which litigation occurs over a lengthy period. If $\mathrm{L}$ is to be prohibited from selling before the litigation commences, then the same prohibition would seem to require that $\mathrm{L}$ also not sell after the litigation commences because of the fact that $\mathrm{L}$ will have information that cannot, in the interests of the litigation, be made generally available. It follows that L could not sell until the litigation was actually concluded, which would delay the liquidation considerably.

If this analysis is correct, does it apply equally to administrators and receivers? There is no obvious reason why it would not apply to administrators. Arguably, this scenario is less likely to apply to administrators prior to a vote on whether or not the company should enter a deed of company arrangement, but if the creditors vote to do so, the administrator's position would seem to be the same as the liquidators.

In general, the only possible difference between liquidators and receivers is the more "privatised" qualities of external administration in the case of a receiver appointed under a charge. ${ }^{49}$ The receiver, when appointed under a charge, is not an officer of the court, unlike the liquidator. Hence, is there any basis for relying on this distinction to differentiate the results? We would argue not. That distinction does not affect any of the efficiency analyses we saw above. Nor is there any basis for saying that what would be fair for a liquidator would be unfair for a receiver, except in terms of the fact that the receiver tends to secure gains for a single secured creditor, rather than (typically) a number of unsecured creditors. This does not seem to be relevant to insider trading liability. The absence of such a basis for distinction is also generally applicable to our conclusions in relation to the following hypothetical. We now turn to our second intra-insolvency trade involving endogenous information.

Scenario 2: $R$, a receiver of company $C$, appointed by bank $B$ under a floating charge, has been made a private offer by a purchaser $P$, who is willing to buy the business undertaking of $C$. The next-best alternative to selling the business to $P$ is to run the business for a further twelve months, to complete the development of a product. C's only other asset, besides the business, is a holding of (listed) securities in company $D$ (currently worth $\$ 2$ million). $C$ undertook a number of business projects with $D$, and owes $D$ a large unsecured debt. $B$ is currently owed $\$ 10$ million, and that debt bears interest at the rate of $10 \%$ pa. C has unsecured debts of $\$ 20$ million, half of which is the debt to D. Apart from the $\$ 10$ million debt owed by

49 J Armour and S Frisby, "Rethinking Receivership” (2001) 21 Oxford Fournal of Legal Studies 72. 
$C, D$ has other assets valued at $\$ 15$ million. P has offered $\$ 8$ million for the business. If $R$ chooses to run the business for a further 12 months, there are two equally likely outcomes - the business will be worth $\$ 8$ million or $\$ 31$ million. The information about that valuation is generally available. $R$ is instructed by $B$ to sell the business and not to develop the company business. Should $R$ sell the securities in $D$ before it advises publicly that it has accepted P's offer?

Scenario 2 features similar elements to Scenario 1. Both situations involve the EA having to decide whether or not to realise an asset before taking an action that will adversely affect those securities. In both cases, the property rights and fiduciary duty approaches tend to militate in favour of permitting the trade.

To model this problem we will again use a three period model. At $t_{0}$, R decides whether or not to sell the shares, and whether or not to accept P's offer. At $t_{1}, \mathrm{R}$ has decided at $t_{0}$ to accept P's offer, but has made that information public before selling the securities in $\mathrm{D}$. We reach $t_{2}$ in circumstances where $\mathrm{R}$ has announced it will not accept P's offer, so that it sells the business at the end of 12 months, with the equal chances of receiving $\$ 8$ million or $\$ 31$ million. Figure 2 demonstrates the payoffs to B, D, and the other creditors, should the sale occur in that period. Figures quoted are in millions for the sake of convenience.

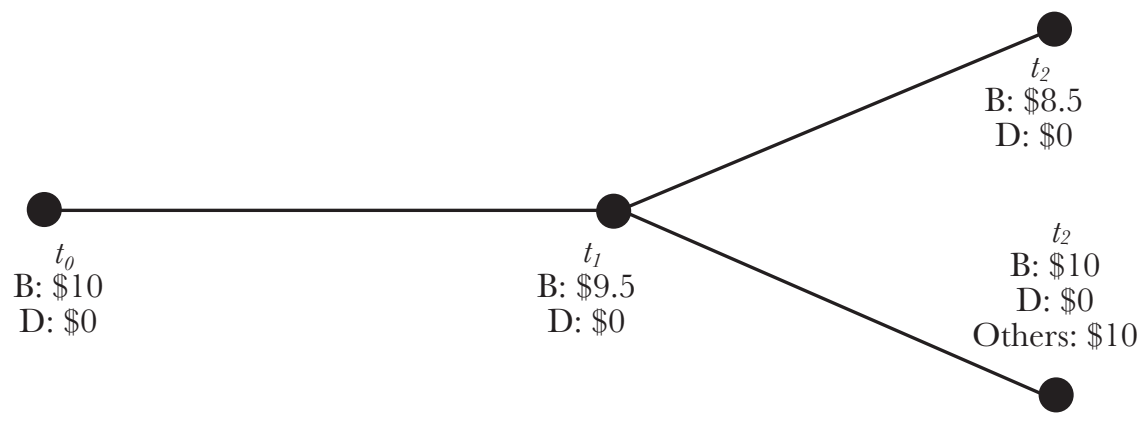

Fig. 2. Payoffs to Bank B and Company D

These figures require explanation. Should R accept P's offer and sell the shares in $\mathrm{D}$ at $t_{0}, \mathrm{~B}$ will break even. The total realisation is $\$ 10$ million, which is equal to the outstanding debt. D receives nothing on the $\$ 10$ million face value of its debt. In order to understand the situation at $t_{1}$, it is necessary to understand the valuation of D's shares. In the absence of information regarding P's offer, the market values D's equity on the basis of its rational expectations regarding the value of D's loan to $\mathrm{C}$. The face value of the debt is $\$ 10$ million. However, at present (ie, prior to knowing about P's offer), there is only a $50 \%$ chance that the debt will be repaid (where the business is worth $\$ 31$ million), and a $50 \%$ chance that $\mathrm{D}$ will not be 
repaid at all. Therefore, the market value of that debt should only be $\$ 5$ million. It follows that the value of $\mathrm{D}$ will therefore be $\$ 20$ million, being that $\$ 5$ million debt and the other assets worth $\$ 15$ million. A $\$ 20$ million valuation implies that B must own $10 \%$ of the equity, since its shares are worth $\$ 2$ million. However, once $\mathrm{R}$ announces it will accept P's offer, the debt is worth nothing because there will be no money for unsecured creditors. $\mathrm{D}$ is then worth $\$ 15$ million, and the value of C's holding in $\mathrm{D}$ will fall by $\$ 500,000$.

If P's offer was rejected, and the business was developed, there are two possible scenarios. Where the business could be sold for $\$ 8,000,000$ (the same amount as P's offer), B will be $\$ 1$ million worse off than it was at $t_{1}$, representing the interest on the debt (the total payoff is therefore a loss of $\$ 1,500,000) .{ }^{50}$ Where the business is sold for $\$ 31$ million, all creditors recover their debts in full. It should be apparent that B's preferences are not perfectly aligned with social welfare. Wealth is maximised where P's offer is rejected, since the expected value of the business in twelve months is $\$ 19,500,000$, which is higher than $\$ 8$ million at $t_{0}$. However, B's expected payoff from accepting P's offer is a payoff of either $\$ 10,000,000$ in $t_{0}$. $\$ 9,500,000$ in $t_{1}$, compared to an expected payoff of $\$ 9,250,000$ in twelve months (the mean of $\$ 10,000,000$ and $\$ 8,500,000)$. So, in the absence of a side deal between $\mathrm{B}$ and $\mathrm{D}$ (and the other unsecured creditors), $\mathrm{R}$ will accept P's offer. Although this is suboptimal, it is important to note that it is clearly not the role of the insider trading provisions to discourage such decisions from being made.

Once again, the case in favour of permitting $\mathrm{R}$ to trade is strong. It maximises recovery for $\mathrm{B}$ for $\mathrm{R}$ to trade in $t_{0}$. Although on the facts of this case the unsecured creditors were no better off for the trade occurring in $t_{0}$, it is clear that had $\mathrm{P}$ offered more than $\$ 8$ million, it would have been in the interests of the unsecured creditors for $\mathrm{R}$, were it of a mind to accept P's offer, to trade in $t_{0}$, not in $t_{1} \cdot{ }^{51} \mathrm{R}$ used the information in B's best interests.

This is a useful example of two points made in the general analysis. First, had $\mathrm{P}$ made an offer that would have increased the value of the shares in $\mathrm{D}$ - as any offer over $\$ 20$ million would do- $\mathrm{R}$ was better off using that private information to abstain from trading in $t_{0}$ and to trade after that information was made generally available. This use of the insider information would be perfectly lawful. It therefore illustrates the caprice associated with not permitting $\mathrm{R}$ to trade where the information is bad rather than good.

Secondly, had $\mathrm{P}$ not made the offer, $\mathrm{R}$ would have sold the stock at $t_{0}$ anyway. It was in R's interests to liquidate that position expeditiously. Therefore, the private information did not change the decision to sell the stock.

It remains a question of fact whether $\mathrm{R}$ would in fact be able to trade $10 \%$ of the stock in $\mathrm{R}$ without moving the price downward, driving the market towards a

50 We assume the appropriate discount rate is $10 \%$, the same as the interest rate.

51 That would be because the total recovery would be greater than $\$ 10$ million, leaving a small payoff for the unsecured creditors. 
more accurate valuation of the stock. The above analysis assumed unrealistically that the price would be unchanged. The more the trade moves the price towards its "true" price, the more efficient is the market in the stock of D. Thus, on balance, Scenario 2 is essentially the same as Scenario 1. It justifies the same general permissive treatment.

\section{(b) Intra-insolvency trades on generated information}

Scenario 3: $V$, the voluntary administrator of company $C$, has decided to sell off $C$ 's $30 \%$ equity interest in $S$, a related company. It is the largest shareholder in $S . V$ has material, private information related to the financial prospects of $S$. Is $V$ permitted to sell off $S$, and what are V's obligations in selling off S?

We have suggested that the answer to this problem may often lie with a specific mandatory disclosure obligation where the securities are sold, rather than via means of insider trading prohibitions. A disclosure obligations in relation to the sale offer is likely to be imposed by law where the offeror has control of the corporation. ${ }^{52}$ However, these are likely to cut in only where there is some form of controlling relation between the insolvent firm and the company in which the securities are traded. A fiduciary duty in equity is also imposed in some situations involving the reverse hypotheticals - where the informed party buys the securities of another shareholder. However, in the situation we are examining here, where only sales are contemplated, and the buyer is unlikely to be owed any fiduciary duty, there is little in the way of case-law in Anglo-Australian law to suggest a duty arises at common law.

The appropriateness of such a solution can be seen by reference to several of the above arguments. Where there is a large secondary offering of securities, a disclosure obligation as a condition precedent is crucial for efficient capital allocation. That seems a reasonable premise, and may even occur in the absence of a formal obligation because of the negative signalling value in the absence of certification.

By contrast where the EA has generated information in relation to securities of a corporation over which he or she has little or no control, the case for an insider trading obligation seems unnecessary. The dominant bases for this proposition are twofold. First and perhaps most importantly, the generation of information in relation to assets to be disposed of is to be expected - such behaviour maintains or increases the value of the EA's reputational capital. Secondly, the EA (especially a liquidator) must often still sell in the relatively short term whether the news indicates the stock is undervalued or overvalued. If the stock is undervalued, a longer term holding strategy is rarely possible, except in a reconstruction. So, the generation of this information has in fact a relatively low net present value because of the absence of a means of capitalising on good news.

52 Corporations Act 2001 s 707. 
(c) Intra-insolvency trades on coincidental information

Scenario 4: $V$, the administrator of company $C$, is told by $D$, one of $C$ 's former directors, that he, $D$, is under investigation for fraudulent behaviour by ASIC in relation to a number of transactions in C's securities that were illegal under the market manipulation provisions in ss 997 and 998. D is the CEO of another company, $E$; $C$ has securities in $E$. If $D$ is convicted, he is likely to barred from management under $s 206 B$ and would be incapable of managing $E$. Vis uncertain when $A S I C$ will disclose its decision to prosecute. Should $V$ sell the securities in E?

To begin, let us consider whether $\mathrm{D}$ would have any right to trade in the stock of $\mathrm{E}$ based on his knowledge that he would likely be barred from its management. The answer to that question would seem clearly to be no. This is one of those cases where it is undesirable to recognise $\mathrm{D}$ as having any property rights in such information warranting protection, in light of his own wrongdoing. ${ }^{53}$ It would be inconsistent with his fiduciary duty.

If $\mathrm{D}$ is prohibited from trading, does it follow that $\mathrm{V}$ also should be? This case is less clear. Unlike D, V does not owe a fiduciary duty to the shareholders of D. Although the information came from a fiduciary, it was important in relation to the affairs of $\mathrm{C}$ and would arguably have come by other means into the possession of $\mathrm{V}$ or any subsequent liquidator of $\mathrm{C}$. The case for saying that the law should not recognise any informational rights in $\mathrm{C}$ which $\mathrm{R}$ could exploit by trading is therefore weaker. However, D's own fiduciary obligations to E may make it arguable that the information communicated to others should be subject to restrictions in their hands as well, to reinforce the fact that the information is not communicated for trading purposes. So, a fiduciary argument does tend to suggest a possible case for prohibition.

However, other points are not quite so clear. Associating the trade with the information, because of the high likelihood that these securities would be sold in any event. In addition, if used for trading, at least half of the coincidental information will not be proscribed to the extent that it is used to defer sales that would otherwise occur. Finally, it is unclear what the impact of such a trade on reputational capital is actually likely to be. In this particular situation, it is not clear whether information conveyed to an EA as an officer of the court, used in the best interests of the estate is, or is not, likely to harm the EA's reputational capital. That is an empirical question. Thus, this issue is unclear, so the divergence between the US and UK systems on one hand, and the Australian, on the other, is less troublesome than elsewhere.

It is easier to resolve Scenario 5 where the information is not derived from the classic insiders of a corporation, but rather from information concerning the business itself.

${ }^{53}$ Jonathan R Macey, Insider Trading: Economics, Politics, and Policy (Lanham, MD: AEI Press, 1991). 
Scenario 5: $L$, the liquidator of company $C$, receives a proof of debt by a Norwegian company, $\mathcal{N}$, alleging that $C$ has used internet software that violates intellectual property rights belonging to $\mathcal{N}$. L also acts as the liquidator of company $D$ which owns securities in company $E$, which also used the same internet software. Should $L$ sell D's securities in $E$ before the information relating to the patent infringement suit becomes generally available?

There are several points of specific distinction. First, there are no fiduciary confusions in this case, as there were in the last case, and the information $\mathrm{N}$ is providing is not confidential. Secondly, the information is not being conveyed to $\mathrm{L}$ in any circumstances that could be regarded as an officer of the court. L learns of it in the context of the liquidation, so its use for that purpose is hardly surprising. Thirdly, the information itself is, arguably, more susceptible to competitive trading than the information regarding the prosecution of $\mathrm{D}$ and its effect on $\mathrm{E}$, since it does not have its origins in the behaviour of company insiders. On the contrary, much of it may be in the public domain. Registered intellectual property rights could be inspected, any non-registered rights (such as copyright) could be scrutinised by examining the original copyright work. The information might also be discerned by examining any parallel litigation commenced by $\mathrm{N}$ in relation to the protection of N's rights.

We may also note generally, before we move on to consider inter-insolvency trades, that if an EA sells its securities, it in fact obviates any future conflict of interest, insofar as one arises from ownership of securities in E. It will then make decisions relating to assisting the prosecuting authorities in relation to share transactions free of those interests. The case in Scenario 5 is slightly more complex, but the case against the trade is no stronger. It is arguable that by holding, rather than selling, the securities in E, L's incentives to resist the claim made by $\mathrm{N}$ in relation to $\mathrm{G}$ may be stronger. This is because of the positive correlation between the value of the holding in $\mathrm{E}$, and the expected value of the proof of debt by $\mathrm{N}$. However, there is no reason why that incentive needs to be stronger, and the creditors of $\mathrm{C}$ are unlikely to desire it. Holding the securities in $\mathrm{E}$ simply increases the company's exposure to $\mathrm{N}$, and the market is unlikely to reward the bearing of that security-specific risk.

\section{(d) Inter-insolvency trades}

We have seen that the US and UK systems are likely to associate a greater level of legal proscription with inter-insolvency trades because of the "primary insider" classification or the "misappropriation" result, whereas the generalised exemption protects liquidators and trustees in Australia. Let us now examine to what extent these trades can be analysed in terms of the factors we have considered above.

In terms of the general policy arguments related to insider trading, the "erodability" of the information advantage remains substantially as it was in relation to 
the analysis of inter-insolvency trades. So there is no real change in this context. What about the creation of new information? This point is again somewhat ambiguous in relation to the incentive effects of inter-insolvency trades. On the one hand, there is a free-rider concern - one group of creditors end up free-riding on the costs incurred by another. In this situation; a ban on insider trading functions as a sort of mandatory rule allowing for excludability in relation to the "public good" quality of the private information. On the other hand, permitting inter-insolvency trades allows for a wider range of securities to benefit from private information. A useful heuristic is to inquire into examine this question in terms of the Coasean bargain the shareholders and creditors of corporations might reach in relation to the use for trading on such information. The concern is that a rule permitting inter-insolvency trades may systematically favour some corporations that hold a larger portfolio of securities, but not others. It is unclear what bargain if any would be reached in this situation.

What about the factors we studied in connection with the interests of the shareholders? Again, these factors point in multiple directions. The accuracy of stock prices presumably increases from the wider scope for trading; moreover, there is a clearer signal if a liquidator sequences two or more trades at the same time. What of the possibility of delay in trading? Inter-insolvency trades may arguably delay the making of disclosures to the markets where there is a larger number of holdings to be traded together. Finally, it is difficult to see how inter-insolvency trades can have any effect on changing investments, as was also true of intra-insolvency trades.

We now turn to examine the factors more specific to trades by EAs. These factors point less equivocally towards the case for a prohibition on insolvent trading. First, it does remain difficult to identify an inter-insolvency trade as being specifically informed. However, two comments can be made in this context. One is that a pattern of trades would tend to point towards evidence of inter-insolvency trades. The other is that there may be some more obvious linkages between trades and private information, the less connected the company owning the securities and the company in whose insolvency the information was generated. An example would be an abrupt sale of securities in a slow-moving insolvency contemporaneously with some other event in another insolvency.

Secondly, we saw above in the context of intra-insolvency trades that the scope for informed trading is highly limited, both because only sales can attract supranormal returns and because of the likely absence of securities to beneficially trade in this context. That attenuated scope weakens the case for imposing liability. However, because the scope for inter-insolvency trade is likely to be greater than in intra-insolvency trades, that argument becomes somewhat more ambiguous.

Thirdly, the reputational capital point, reinforced by fiduciary duties represents the strongest argument against inter-insolvency trades. The possibilities for overreaching, such as preferring other principals to the one engaging the EA, delaying decisions or disclosures to complete trades, and so on, all represent areas which 
would be expected to affect negatively the value of the EA's reputational capital. This is consistent with the fiduciary prohibitions on conflicts of interest and secret profits to which EAs are subject.

Thus, on balance, the case for prohibiting inter-insolvency trades is quite strong - it is clearly stronger than the case in relation to intra-insolvency trades. This tends to confirm the approach of the less specific US and English systems to these trades, and tends to be inconsistent with the approach of the generic exemption in the Australian system. We now briefly examine each of these scenarios in turn. Scenario 6 and 8 are illustrative.

Scenario 6: L, a liquidator of company $C$ is considering initiating a suit on behalf of $C$ against company $D$ alleging misleading and deceptive conduct. Company $C$ does not hold stock in D, but company $E$, of which $L$ is also the liquidator does hold stock in $D$. L trades $E$ 's stock before information regarding the suit of $C$ against $D$ is publicly available.

Scenario 8: L, a liquidator of company $C$ is considering initiating a suit on behalf of $C$ against company $D$ alleging misleading and deceptive conduct. Company $C$ holds stock in $D$, as does company $E$, of which $L$ is also the liquidator. L trades $E$ 's stock first, and then D's stock next, before information regarding the suit of $C$ against $D$ is publicly available.

Here, we can see the appeal of a prohibition because of the larger fiduciary concern. This is more intense in Scenario 8 than Scenario 6, because of the more obvious conflict of interest in this particular situation, and the more obvious impact on the reputational capital of the EA. Scenario 7 involves an even stronger conflict of interest. The concern is that insider trading may cause that information to come to light, doing harm to the company seeking the advice, not just reducing the profits of one principal for the benefit of another.

Scenario 7: $L$ is a registered liquidator and offers advice in relation to financial reconstructions. Company $C$ seeks advice in relation to financial reconstruction. Company $D$, which holds securities in company $C$, commences winding up and $L$ is appointed the administrator. Can $L$ sell D's securities in $C$ ?

At least part of the information - the decision of C's management to seek the advice of $\mathrm{L}$, and any information they impart to $\mathrm{L}$ - is both private and confidential. If market participants decode the information content of L's trades, C could be substantial injured. The appropriate, ethical course of conduct, above and beyond insider trading issues, is for $\mathrm{L}$ to disclose its conflicts of interest to $\mathrm{C}$ - the fact that it is acting for D, which owns stock in $\mathrm{C}$, and for transactions in that stock to proceed with the consent of $\mathrm{L}$. We would argue that in the absence of explicit and well-informed consent (unlikely to be given), L's transaction should be 
contrary to law. Difficult questions of proof remain. It continues to be difficult to determine whether $\mathrm{L}$ is, or is not, selling on the basis of the insider information or has determined to sell the securities prior to the information coming into his possession.

\section{(e) Procuring and Communication}

The concerns associated with the EA procuring or tipping trades are clear and they make for an obvious case for proscription. Fiduciary and reputational capital concerns make this clear, and tipping vastly opens up the scope for wider insider trading - buy transactions become possible. There is also a clear risk of expropriating information that is contrary to the incentives to create new information. Thus we have Scenario 9:

Scenario 9: $R$, a receiver of company $C$, appointed by bank $B$ under a floating charge, has come into possession of private information gleaned from the conduct of the receivership regarding the securities of company $D$. $C$ does not own securities in $D$, but B owns put options on D's shares. May $R$ communicate that information to the officers of $B$ prior to that information becoming generally available?

Scenario 9 involves a clash between two legitimate aims. On the one hand, it is necessary for there to be uninhibited communication flows between $\mathrm{R}$ and $\mathrm{C}$. C appoints $\mathrm{R}$ to represent its interests, and it is appropriate for $\mathrm{C}$ to be able to discuss matters arising in the receivership in order to maximise the welfare of $\mathrm{R}$. On the other hand, it may be undesirable for $\mathrm{C}$ to trade on that information. Scenario 9 is an example which is poised somewhere in the middle ground. The fact the information concerns another company suggests that the possibility of strategic trading is relatively low. However, other scenarios could be developed in which trading by others could be much more problematic. One situation is where the information concerns securities, particularly debt securities, in an externally administered firm in which there is a surviving market in the firm's securities or the securities of a firm within, say, the corporate group. Trading on that information could be highly problematic because of the likelihood of non-competitive trading on that information close to the time of its revelation. In the United States, this is an acknowledged problem in creditors' committees in the reorganisation of insolvent firms under Chapter 11 of the Bankruptcy Code ${ }^{54}$ Clearly, it is not a problem for the EA who will only be concerned with the sale of the firm's assets, not with trading in the firm's securities. However, the concerns in connection with the creditors feed back into the appropriate policy to be applied to the communication of information. It is reasonably clear that the exemptions for liquidators in Australian law do not apply to the communication of information to creditors

54 Bankruptcy Code, 11 USG ss 328(c) and 330(b) and Pozen and Mencher, supra note . 
(since the provision speaks of "transactions entered"), and of course those provisions do not apply to receivers or administrators. ${ }^{55}$

It would seem that the appropriate course of action lies in the existence of satisfactory Chinese Walls within the creditor-appointor. Chinese Walls are necessary to ensure that there is a divorce between the person to whom information is communicated concerning the insolvency (eg, the officer responsible for the loan) and the person who may make decisions regarding trade in the securities. ${ }^{56}$

\section{(f) Conclusion}

The purpose of this section has been to illustrate the need for the law to take a relatively complex and contingent approach to the regulation of informed trading by EAs. We have seen that many of the policy arguments that have been proposed in the economic analysis of trading by classical insiders have limited weight in this context. However, there are a distinct set of policy arguments which explain why some forms of informed trading, such as intra-insolvency trades, especially on endogenous and generated information, are not usefully prohibited, whereas others, such as inter-insolvency trades should be unlawful. This set of results is, surprisingly, most likely to be consistent with the outcomes of applying the US and UK regimes, which have been formulated without explicit reference to informed trading by EAs, as opposed to the sui generis exemption for trades by liquidators which is used in the Australian regime. The contrast is interesting - it makes more sense for the law to try to reinforce the results that analysis suggests that reputational capital would reach (such as permitting intra-insolvency trades, and prohibiting inter-insolvency trades), rather than simply assuming that legal sanctions have no place in the regulation of trades by liquidators.

In the next part, we consider some possible ways of devising an optimal regulatory process for informed trading by EAs. This attempt is based on the notion that even though the US and UK methods do approximate the intuitively efficient results, there may well be more sophisticated and appropriate regulatory responses to this problem.

55 The communication of information concerning securities that are still traded is arguably most relevant to receivers and administrators, because these methods (especially the former) are more likely to involve reorganisation of the firm.

56 At present, the Australian legislation enables a Chinese Wall to provide protection to the creditor. However, it is by no means clear that it similarly exculpates an EA from the breach of s 1002G(3) should he or she communicate information to the creditor's representative. The problem lies in the fact that s 1002G(3) states that the insider must not communicate information "to another person if the insider knows, or ought reasonably to know, that the other person would or would be likely to (a) ... purchase or sell ... securities". If the corporation for which the second works itself is to be regarded as a person for the purposes of that section, it is not clear that the presence of a Chinese Wall affects the application of the communication offence. 


\section{E. The Form of Insider Trading Prohibitions: The Way Forward}

We saw in the above sections that the optimal regulatory method that should apply to informed trading by EAs is unlikely to be greatly influenced by some of the longstanding policy premises such as fairness, investor confidence, equal access, and even the accuracy of market pricing. The other factors that are more relevant do not lend themselves to simple solutions but vary depending on the context of the trade and the information, and the second-order problems associated with the application of the legal rule. That may be why more complex and contingent legal regimes applicable to insider trading actually perform more creditably than the one which provides a carte blanche exemption for informed trades by EAs. In this section, we relax the method adopted above of comparing existing methods, and examine some of the parameters that an optimal regulatory approach might actually take in this area.

\section{Distinction Between Types of External Administrators}

The analysis in this article has not supported the current division between the transactions entered by liquidators (which are excluded from the scope of the insider trading provisions by the regulations) and other EAs (to whom the provisions apply with full force). A distinction in legal treatment is not appropriate. It is possible that certain types of EAs, such as privately appointed receivers in English law, are more likely to engage in the forms of informed trades more warranting proscription (for example, procuring and communication, inter-insolvency trades). However, that does not seem to be any basis for differentiating the application of the laws. It simply suggests an empirical proposition that there will be variation in the incidence of appropriately proscribed trades amongst different categories of EAs.

\section{Proscribed Trades}

The gist of our analysis in Section D was that inter-insolvency trades should be prohibited. By contrast, there is a stronger case for permitting intra-insolvency trades. In relation to those trades, we saw that some trades on coincidental information (for example, Scenario 4) justify a prohibition because the trade is inconsistent with the circumstances in which the information was acquired. The optimal provision therefore has the following elements:

(a) it would impose a general prohibition on trades by EAs that are based on private information, and also on the communication of information to other persons unless those communications are protected by law;

(b) it would exclude from that prohibition those trades based on private information that was revealed to or generated by the EA in the course and 
context of the administration of the insolvent estate which includes the securities the subject of the trade;

(c) the exemption in (b) is contingent on the use of the information not being inconsistent with the obligations of confidentiality or secrecy assumed in receiving or generating that information, or in undertaking the administration.

This enables us to differentiate Scenarios 4 and 5 without prohibiting trades on endogenous or generated information. On the other hand, the provision does not require the drawing of a hard and fast line between any of the information categories. This is desirable as the line between generated and coincidental information may sometimes be highly imprecise.

\section{Distinction Between Types of External Administrators}

Is there a case for obliging the EA to disclose his or her trades? Disclosure may be imposed at one of two different times. One is before the trade occurs - the EA would signal his intention to sell a particular holding of securities. Jesse Fried has advocated this as a model that might decrease the incentive to engage in insider trading. The other is after the trade occurs - the EA reports the trades he or she has engaged in, some defined period after the trade occurs. An analogous obligation exists under s 16 of the Securities Exchange Act. The timing of the obligation would be expected to have an impact on the returns associated with the trade.

A pre-trade disclosure obligation should naturally decrease the profits to informed trade, but only where the market expects the insider to possess private information. As we have seen, however, sales by EAs may often be uninformed liquidity trades undertaken to realise the value of the firm's assets. Can the market tell the informed from the uninformed trades? As much as the market might meaningfully evaluate is a probability that a trade is informed based on the likelihood that a company's securities will be affected by the insolvency or that the EA will be in a position to generate information about the securities. So a pre-trade disclosure would convey some information, but not all that much.

We might also ask whether a pre-trade disclosure requirement is really needed for informed trades by EAs. There is something to be said for the contrary view. As Fried argues, the measure of returns by insiders is huge. That these losses are sustained by uninformed traders makes it imperative to decrease the measure of these returns in order to retain liquidity in the market. Although it is ultimately an empirical question, the absence of constraints on unfettered trading by the EA on private information suggests that the magnitude of returns from these trades is limited (so diminishing the case for such intervention).

By contrast, an ex post mandatory disclosure obligation may be of some value. Consider an obligation to report one's trades within three to five trading days after the sale by the EA. To the extent that the EA is likely to be informed, it is desir- 
able to ensure that trading decisions are notified to the market expeditiously. This assists the market to adjust to new information. In addition, it enables the market, creditors, and other interested parties to monitor the behaviour of the EA and to re-evaluate the measure of his reputational capital. It may also be appropriate to impose two other forms of disclosure obligations. First, it is desirable to ensure that any persons acting as EAs who do advisory work have obligations to disclose to the advisory client any interests that the companies they administer hold in the client's stock. Such a disclosure obligation allows conflicts of interest of the sort that arise in inter-insolvency cases to be monitored.

At the same time, the legislation should make it clear that EAs are responsible for disclosing endogenous and generated information to the market on a timely basis. That provision should oblige the EA to disclose to the market any information of which the EA is aware that is:

(a) not generally available,

(b) relates either to the effects or outcomes of the administration or the value of assets owned by the administered firm;

(c) is likely to be relevant to the valuation of:

(i) any securities of the corporation, that continue to be traded,

(ii) other exchange-traded securities.

That provision, combined with the intra-insolvency insider trading exemption, would have the effect of bringing the relevant information to the market sooner. It is desirable to have both the exemption for the informed intra-insolvency trades and the disclosure obligation - without the exemption, the EA may want to evade the obligation because of its effect on the estate; without the disclosure obligation, the EA's information may take excessively long to reach the market. It would be appropriate to impose a maximum period of, say, a one-day trading period following a trade in which the information relating to those securities must be disclosed.

To conclude, we argue that the the appropriate responses to informed trades by EAs involve prohibiting inter-insolvency trades and permitting intra-insolvency trades, which are free of misappropriation-type elements. These principles ought to be supported with an obligation to disclose trades, to disclose all relevant conflicts of interest, and to disclose private information as it becomes available. This represents a more practical set of responses to the nature of informed trading by EAs.

\section{F. Afterword}

On balance, these provisions provide a more rational basis for regulating insider trading by EAs. The area is one in which the need for legal protection is limited, compared with other areas of trading involving insiders. The law needs to respond 
to this problem by a provision that is capable of achieving the finer balances than the current law which combines a flat prohibition with a blanket exemption for liquidators. We have recommended a broad exemption for all classes of EA, coupled with a disclosure obligation and an obligation to trade "all or nothing" of the corporation's securities. This would be a significant advance in the law. 